\title{
Racial 'Sterility' and 'Hyperfecundity' in Fascist Italy. Biological Politics of Sex and Reproduction
}

\author{
Maria Sophia Quine \\ Formerly Senior Lecturer in Modern European History, Queen Mary, University \\ of London. Currently Senior Research Fellow in Modern History, University of \\ East Anglia and Visiting Fellow, History of Science, Institute of Germanic \\ and Romance Studies, University of London \\ M.Quine@uea.ac.uk
}

\begin{abstract}
This article explores a new dimension in fascist studies, eugenic studies, and the more mainstream history of Italy, Europe, and modernity. It asks scholars to reconsider the centrality of race and biology to the political programme of Italian fascism in power. Fascism's 'binomial theorem' of optimum population change was characterized as a commitment both to increase the 'quantity' (number) and improve the 'quality' (biology) of the Italian 'race'. These twin objectives came to fruition in the new scientific and political paradigm known to contemporaries as 'biological politics' and to scholars today as 'biopolitics'. Fascism, this article contends, attempted to utilize the full force of the new 'biopower' of reproductive and biogenetic medicine and science in order to realize the aims of its biopolitical agenda for racial betterment through fertility increase. In Italy, fascism encouraged science to tamper with the processes of human reproduction and to extend genetic understanding of diseases which were seen as 'conquerable' without sterilization and euthanasia. It began a biotechnological 'revolution' that historians often attribute to twenty-first-century science. By exploring the technical innovations in assisted conception which Italian fascism promoted, this article challenges the assumption in much of the scholarship that there was a huge divide between the 'old' eugenics of the interwar period and the 'new' genetics of recent decades.
\end{abstract}

\section{Keywords}

fascism; biological politics; fascist biopolitics; fascism and race; racial 'sterility'; biotypology; sexology; fertility; 'hyperfecundity'; assisted conception; the new biology; eugenics and genetics; repro-medicine; Italy

*) I would like to thank Francesco Cassata, Roger Griffin, Marius Turda and the fourth, anonymous reader appointed by this journal for reading and commenting on the draft of this piece. This article is based on a paper, entitled "Hyperfecundity", Biotypology, and Race in Fascist 
In 1994, Dr. Severino Antinori, a Rome-based gynaecologist and embryologist, became famous when he helped a 63-year-old Italian woman - at the time the oldest known woman to give birth - to have a baby through hormone therapy, along with the in vitro fertilization of donor eggs and the implantation of embryos. A pioneer in the use of ICSI (intra-cytoplasmic sperm injection), the inventor of a cutting-edge micro-injection technique for infertile men, and a world leader in research into human cloning to enable pregnancy, Antinori had begun his career as a veterinary biologist before deciding to specialize in this controversial field of medicine. Known already within his own country for his outspoken support of birth control and sexual freedom, the doctor found the sensation caused by the story uncomfortable. He confronted a daily onslaught of media allegations that he was a dangerous 'Wild Bill Hickok' in an unrestrained Italian 'Wild West', where fertility treatment was freely available and often funded liberally by the state in its public hospitals. The entire system and the very idea of assisted conception itself was put on trial and widely condemned by the media. The government-run Queen Helen Hospital in Milan possessed the largest such facility in the country and enjoyed a world-class reputation for its unusually high success rates. It and other leading units nationwide came under attack for being 'factories' where 'unnatural' and 'unholy' practices in bio-medicine were researched and developed. By 2006, when Antinori helped Dr. Patricia Rashbrook, a 62-year-old psychiatrist from East Sussex, become, officially, 'Britain's oldest mother', this maverick had turned into a reluctant renegade, hunger striker, and outlaw in his own land. Accusing the authorities of outright persecution, harassment, and defamation, and with his private clinic under constant police surveillance, Antinori had been forced to provide Rashbrook's treatment in a top secret venue, in an unknown country in Europe. ${ }^{1}$

Antinori's international research centre and clinic had succumbed to the sustained pressure of what he called an 'Inquisition', seeking to impose an 'anti-humanism, absolutism, and fundamentalism', which are 'more dangerous than that of Ayatollah Khomenei'.2 Italy's status as a leading nation in reproductive technology and treatment was already under threat by the Vatican, its bishops, and its faithful. In 2004, the Holy See and its right-wing and clerical

Italy: Good, Reformist, “Latin” Eugenics in Action?', which I presented to the workshop on 'Puériculture, Biotypology, and "Latin" Eugenics in Comparative Context', organized by the History of Race and Eugenics Research Group, at the Maison Française d'Oxford, Oxford University, 20 April 2012.

1) 'Il Prof. Severino Antinori intervistato da Liana Radici' for 'Weekend in Salute' radio programme, Radio IES, 18 January 2012; G. Sinha. 'Cloning Update.' Science, 260 (2002) 1, 61.

2) D. Pacitti. 'Catholic Church vs Saviour of Childless.' The Times Higher Education Supplement, 6 October 2000. 
supporters had succeeded in their campaign to press the Berlusconi government to pass new draconian laws severely tightening the rules on fertility. Within months of the passage of the new curbs, fertility clinics nationwide reported that the misery caused by unwanted childlessness had increased manifestly as a consequence of their plummeting success rates. Quite dramatically, the strict bans gave full personhood in law to embryos from the moment of conception; they also called a complete stop to the genetic screening or freezing of pre-implanted embryos (though foetuses can still be screened and aborted on eu-genetic grounds and for personal reasons). Furthermore, no sperm or egg donation, or IVF for gays or single women, or surrogacy or embryo research, is now permitted. Critics of the strict regulatory regime have voiced fears that the change was just the beginning of a bitter bio-war waged by this, most conservative pontiff. The German-born Benedict XVI has publicly declared his opposition to abortion and 'euthanasia', even in its therapeutic, post-1945 form as palliative care for terminally-ill patients. Women's rights' activists and concerned physicians have proclaimed that the Catholic Church is wholly committed to a 'medieoval religious crusade' against science and 'progress' with the aim of clawing back the hard-won cornerstones of post-war Italy's socio-sexual modernity, which was consecrated in landmark referendums in 1974 and 1981 legalizing divorce and abortion. They have warned of the huge potential for oppression and suffering in the new theocratic reproductive order and called for a return to secularism, choice, and democracy. ${ }^{3}$

This article locates these current struggles surrounding the new reprogenetics of recent decades in their rightful context, which is - where they all began - in the old eugenics of the inter-war period. In the study of eugenics, this continuity of medical practice and scientific research has a bearing on one of the most important questions concerning scholars today, the conceptualization of the links between the old and the new. ${ }^{4}$ In Italy, no clear-cut distinction between the two ever really existed, in any event. It is well to remember in this regard that the Italian Committee for the Study of Eugenics of 1913 was re-founded as the Italian Genetics and Eugenics Society in 1919. Moreover, a quite distinctive Italian tradition of pro-conceptive reproductive science and medicine that arose in the liberal period and gained state sponsorship under Mussolini's dictatorship continued to flourish after 1945. My intention is also to address some key issues and misconceptions in the literature about both

3) T. Smith. 'Fertility Laws Frustrate Italians.' BBC News: Europe Report, 9 August 2004.

4) 'Eugenics Old and New', Special Issue of New Formations, 6o (2006-2007), eds. C. Burdett and A. Richardson; M. Ekberg. 'The Old Eugenics and the New Genetics Compared.' Social History of Medicine, 20 (2007) 3, 581-93; A. Bashford. 'Epilogue: Where Did Eugenics Go?' In The Oxford Handbook of the History of Eugenics. Eds. A. Bashford and P. Levine. Oxford, New York: Oxford University Press, 2010, 539-58. 
Italian and 'generic' fascism. In fascist studies, a tendency to see an apparent exceptionalism in Nazism has experienced resurgence in recent years at the same time that the theory of 'totalitarianism' has returned in a new post-Cold War format. ${ }^{5}$ One of the singular features of National Socialist Germany, for many scholars, was its unparalleled, fanatical drive to create a racial utopia. ${ }^{6} \mathrm{~A}$ contention of this piece is that the by no means unique antinatalist policies of sterilization, 'euthanasia', and genocide (especially now that forced sterilization is defined in international law as genocidal) have dominated and skewed thinking, somewhat, and obscured the reality that these were and are not the only determinants of a biological and racial prime directive.

Giving credence to Germano-centric perspectives, Italianists working within the mainstream of traditional political and now culturalist histories, which predominate, have come to embrace the view that one of the particularities of Italian fascism was that the 'racisms' which it espoused were largely cultural, spiritual, or nationalistic, but not 'Social Darwinist', scientific, or biological until 1938. ${ }^{7}$ Even Nicola Pende, the arch-typical bio-medically driven scientist and policy-maker, whose science of biotypology aimed first and foremost to increase fecundity through endocrinology, has been depicted as a proponent of 'nationalistic-spiritualistic racism' (whatever that really means). ${ }^{8}$ Scholars have focused rather a lot upon the July 1938 'Manifesto of the Race', the subsequent laws 'for the defense of the race', and the journal La Difesa della Razza (1939-1946), which are often described as the first manifestations of biological racism in fascist Italy. ${ }^{9}$ The biological and racial constituents of the anti-miscegenation legislation accompanying the conquest of empire in 1935-1936 have also been underplayed. ${ }^{10} \mathrm{~A}$ re-conceptualization of

5) P. Grieder. 'In Defence of Totalitarianism Theory as a Tool of Historical Scholarship.' Totalitarian Movements and Political Religions, 8 (2007) 3-4, 563-89.

6) Z. Sternhell. The Birth of Fascist Ideology: From Cultural Rebellion to Political Revolution. Princeton: Princeton University Press, 1994, 4-5; I. Kershaw. Hitler, the Germans, and the Final Solution. New Haven: Yale University Press, 2008, 345, 356.

7) M. Raspanti. 'I razzismi del fascismo.' In La menzogna della razza: Documenti e immagini del razzismo e dell'antisemitismo fascista. Ed. Centro Studi F. Jesi. Bologna : Grafis, 1994, 73-89.

8) G. Israel and P. Nastasi. Scienza e razza nell'Italia fascista. Bologna : Il Mulino, 1998, 12, 336. See too: F. Cassata. 'Nicola Pende Scienziato Razzista.' La Repubblica, 14 September 2006, and: F. Cassata. Building the New Man: Eugenics, Racial Science, and Genetics in Twentieth-Century Italy. Budapest, New York: Central European University Press, 2011, 7.

9) See, for example: G. P. Romagnani. Le interdizioni del Duce: Le leggi razziali in Italia. Torino: Claudiana, 2002; V. Pisanty. La difesa della razza. Milano: Bompiani, 2006; F. Cassata. La difesa della razza: Politica, ideologia, e immagine del razzismo fascista. Torino: Einaudi, 2008.

10) G. Bernardini. 'The Origins and Development of Racial Anti-Semitism in Fascist Italy.' Journal of Modern History, 49 (1977) 3, 431-53, 442; and: E. M. Robertson. 'Race as a Factor in Mussolini's Policy in Africa and Europe.' Journal of Contemporary History, 23 (1988) 1, 37-58. My contention is that efforts to prevent racial 'cross-breeding' and create sexual 'apartheid' in 1936 
fascist 'racism' is in order. In some of the literature, anti-Semitism is confused for racism. ${ }^{11}$ Some scholars prefer to define 'biological racism' simply and simplistically as an embrace of the idea of 'purity of blood.' ${ }^{12}$ Historians have come under the influence of German history in this regard and, still working within this Germanic template, they have also equated racism with supremacism. With an implicit comparison to Nordicism in mind, they have argued, incorrectly, that supremacist belief was largely absent from Italian culture. ${ }^{13}$ There still is a very real reluctance or inability to view Italian history on its own terms, free of assumptions based upon the German and Nazi experience. Sometimes, there is just, it seems, a desire to hold on to a romantic notion of Italy as being a nation of 'brava gente' somehow immune to those sentiments more common to 'others', like the Germans. ${ }^{14}$ This article does not seek to undervalue the significance of the increasingly exclusionist racism which the Italian fascist dictatorship unleashed in a whole series of policies and actions affecting East Africans, Albanians, Arabs, Slovenes and the Jews. But due consideration to these realities should not prevent scholars from recognizing that race had primacy for Italian fascism, as movement and regime, long before 1938. Moreover, race was central to the Italian fascist state in ways that have hitherto not been fully or widely understood.

Historians of science and medicine appreciate the extent to which scientific racism and eugenics became the matrix of fascism's vision of a New Man, New Woman, and New Order and informed policy choices and initiatives within a purposeful and 'programmatical' dictatorship determined to improve the

\footnotetext{
were not largely symbolic acts or the sudden start of an overtly racist agenda; rather, they were a manifestation of fascist biopolitics put in action once historical exigencies, such as the 'conquest' of empire, made them policy imperatives.

11) The conflation of anti-Semitism with racism, and even the depiction of anti-Jewish sentiment and action with something called anti-Semitism, is especially baffling and problematical, as it is premised on an acceptance of the idea, derived from nineteenth-century philology and anthropology, that the Jews are a 'race' and a 'Semitic' one at that (which has relevance only in relation to a supposed 'Aryan' race). G. Israel and P. Nastasi, Scienza e razza nell'Italia fascista, sees the problem of Italian racism only in relation to anti-Semitism. G. Fabre. Mussolini razzista: Dal socialismo al fascismo: La formazione di un antisemita. Milano: Garzanti, 2005, equates the two.

12) G. Israel and P. Nastasi. Scienza e razza nell'Italia. 209.

13) A. Gilette. Racial Theories in Fascist Italy. London: Routlegde, 2002, introduction and 95ff; this sees Italian manifestations of biological racism in relation to Nazism, Nordicism, and the Holocaust.

14) Even Italian eugenics, whose entire ideational universe revolved around a conception of biological race, in common with other national varieties, can be depicted, oddly, as being largely race-free: C. Chimisso. 'Fleeing Dictatorship: Socialism, Sexuality, and the History of Science in the Life of Aldo Mieli.' History Workshop Journal, 72 (July 2011), 31-51, 42; L. Reale. Mussolini's Concentration Camps for Civilians: An Insight into the Nature of Fascist Racism. Portland: Mitchell, 2011, attempts to debunk this myth of the 'brave Italians'.
} 
quality and increase the quantity of the Italian race. ${ }^{15}$ The central argument herein is that the Italian fascist dictatorship possessed a commitment to an overarching racial imperative and pursued a 'total' and totalizing biopolitical programme no less obsessively than the Nazi regime did. But Fascist Italy's overriding racio-biological objective was different from that of Nazi Germany. Italian fascism sought to increase, by each and every socio-biological and reprotechnological means, racial prolificity, rather than safeguard racial purity. My attempt is to contribute to on-going research in fascist studies by exploring this somewhat neglected aspect of Italian population/health/race/social/welfare policy and to argue in favour of historical specificity rather than exceptionality. My aim is also to explore aspects within the history of science and eugenics which have not enjoyed much attention.

Within eugenic studies, the single issue of sterilization has been the prime focus of scholars, even in countries where this measure never achieved widespread support or ever became a serious policy option for government. The majority of works on eugenics concentrate on so-called 'negative' eugenics. Indeed, in some investigations, eugenics is definitionally reduced to little more than advocacy of sterilization. When 'positive' eugenics is examined, moreover, it is mainly through 'the social' aspects of it, such as health and welfare reform. ${ }^{16}$ This article, by contrast, seeks to explore an important dimension of positive eugenics that pertains to the domain of 'the biological'. The intention is to investigate the advance under fascism of bio-medicine and biotechnologies aimed at increasing the reproductive fitness of human beings. My argument is that, in the pursuit of its pronatalist ambitions, Italian fascism sought to increase and utilize the power of the new biology. Through reproductive medicine and technology, modern biology, unlike the old largely observational biology, claimed mastery over basic life processes and forces, such as fertility. Because of its fanatical natalism and nativism, Italian fascism transformed the whole political landscape and language and multiplied the points of intersection between biology and politics. In opposition to religious traditionalism, it championed a form of bioprogressivism with a procreative purpose, pioneered a brave new state-directed biopolitics, and charted unknown territory in the scientific manipulation of sex and reproduction. My ultimate aim is to integrate the study of fascism and eugenics more fully by exploring direct linkages between science and the state in the articulation of this

15) On biological modernism, modernity, eugenics and fascism: R. Griffin. Modernism and Fascism: The Sense of a Beginning under Mussolini and Hitler. Basingstoke, New York: Palgrave Macmillan, 2007, chapter 1 and 351 and: M. Turda. Modernism and Eugenics. Basingstoke, New York: Palgrave Macmillan, 2010, 100-1.

16) M. S. Quine. Italy's Social Revolution: Charity and Welfare from Liberalism to Fascism. Basingstoke, New York: Palgrave, 2002, ch. 5 and: 'The First-Wave Eugenic Revolution in Southern Europe: Science sans frontiers.' In The Oxford Handbook of the History of Eugenics, 
distinct Italian eugeni-fascism which was predicated on a notion of biological race and focused determinedly on a desire to preserve, protect, and enhance fertility.

\section{The Nightmare of National Degeneration}

Italian fascism did not invent the vocabulary and vocation of the new biopolitics. Rather, it exploited the idiom of eugenics to define and describe the purpose of its programme to increase the quantity and improve the quality of the Italian race. So clearly articulated in the pronouncements and policies surrounding the official launch of the pronatalist campaign in 1925, the biological aims of the Italian fascist dictatorship derived from eugenics. At the core of the eugenic imaginary in Italy was a belief that conception, fertility, sex and reproduction were the keys to racial progress. So many prewar Italian eugenicists shared the aspiration that the life processes pertaining to procreation could and should be controlled and directed to the benefit of the race. The eugenic vision of a future Utopia amounted, in essence, to a conviction that science and government together would take command of human biology. The starting point of eugenic ideas about the need to regulate reproduction was the end-of-century crisis, in evidence from the 1880 os $^{17}$ Pessimism amongst intellectuals of all political persuasions derived from widespread recognition of the total impoverishment of post-unitary liberal politics and statecraft, as well as from a pervasive disenchantment with Italy's seemingly perpetual status as a second-rate, 'backward', and 'inferior' nation, when compared to the great powers and empires of Europe. The principal founder of Italy's first eugenics society (Comitato italiano per gli studi di eugenica), in 1913 as a study group within the Società romana di antropologia (Roman Anthropological Society) which he had established in 1893, Giuseppe Sergi (1841-1936) personifies the scientific and political context of the prolonged and profound 'cultural revolt', modernist upheaval, and paradigm shift in 'consciousness and society' out of which eugenics arose.

The new biology was the foundation of Sergi's scientific work and mission. A year before Wilhelm Wundt produced his monumental Grundzüge der Physiologischen Psychologie (1874) (The Basics of Physiological Psychology), Sergi published his Principi di Psicologia (The Principles of Psychology), a work

377-97. Belief in biological race need not necessarily, but could lead to selectionist or exterminationist positions. In the Italian case, the majoritarian eugenicist viewpoint, though based upon a commitment to fostering improvements in the 'quality' or biology of the race, was firmly in favor of a 'positive', reformist, and health-welfare-oriented platform.

17) For a revisionist interpretation of the longer term cultural and scientific developments that contributed to the rise of eugenics in Italy, see M. S. Quine, 'Making Italians: Aryanism and 
which aimed at grounding modern Italian psychology in biology. ${ }^{18}$ Though he is better known as a physical anthropologist, Sergi founded the kingdom's first laboratory of psychology in Rome in 1876, presided over the First International Congress on Psychology in Rome in 1905, and was pivotal in the creation of the Italian Psychological Society in 1911. Along with ethnology, psychology became one of the official pillars of Italian anthropology in $1878 .{ }^{19}$ Sergi's interest in the psycho-somatic interplay would enrich his anthropological work of the $1880 \mathrm{~s}$ and beyond, which was craniometric and craniological in nature, but also morphological and psychological in style. As a psychologist, his primary focus was on the social rather than the individual. In his anthropological texts, which were all concerned with the study of race, these foci coalesced in a methodology that was just as concerned with the psychological and personality traits as with the physiological determinants of racial types. Galtonian conceptions of inborn 'genius', which he applied to the study of male, female, and racial constitutions, and which he used to refute Lombrosian simplifications of evolutionary regression and human behaviour, were formative in his thinking. ${ }^{20}$ But, above all, Spencerian evolutionism and sociology, which he favoured over Darwinism, provided the wellspring of his ideas. Until he became a fullyfledged eugenicist, just before the war, Sergi did not share the belief of his main mentor, Herbert Spencer, in constant, inexorable progress or 'Victorian meliorism'. ${ }^{21}$ The depressing realities of life in liberal Italy obliterated any optimism that he might have felt and immersed him in the dark abyss of Morelian degenerationism.

For over twenty years, Sergi maintained a rather gloomy outlook. In the 188 os and 189os, the problem of phylogeny, as elucidated through the study of crania, was the principal focus of his scientific research. He was constructing

Anthropology in Italy during the Risorgimento.' In the conference proceedings Crafting Humans: From Genesis to Eugenics and Beyond. Eds. M. Turda and S. Antohi (forthcoming, 2012), 101-28.

18) Wundt is often considered the 'father' of modern psychology. However, the first volume of Herbert Spencer's groundbreaking Principles of Psychology appeared in 1870 and the second in 1880 ; G. Sergi. Principi di psicologia sulla base delle scienze sperimentali. Messina: Stamp. e Stereotipia Capra, 1873, and his Elementi di psicologia. Messina, 1897.

19) In 1878 , Paolo Mantegazza, the holder of Italy's first chair in anthropology and the founder of Italy's first anthropological society, changed the name of the Florence-based Italian Society of Ethnology and Anthropology into the Italian Society of Anthropology, Ethnology, and Psychology.

20) See, for example: G. Sergi. 'Se vi sono donne di genio.' Rivista di antropologia, 1 (1894) 2, 16783; Se vi sono donne di genio. Torino: Bruno, 1894; Degenerazione e genio in Leopardi: lettera del 7 maggio 1898 ad invito del Comitato per il centenario leopardianou. Torino: Bocca, 1898; Gli uomini di genio. Roma, 190o; and L'evoluzione umana individuale e sociale: fatti e pensieri. Torino: Bocca, 1904.

21) Sergi contributed to the Italian editions of Spencer's works: Le basi della morale, intro. G. Sergi ( $2^{\text {nd }}$ rev. ed.: Milan, $\left.1886 ; 1884\right)$ and Introduzione allo studio della sociologia, preface by G. Sergi (Milan, 1881 and $2^{\text {nd }}$ ed: Milan, 1887). Lamarckism fuelled Spencer's positive and 
his system of racial taxonomy and evolution culminating, at the turn of the twentieth century, with the presentation of his grand theory of the African origins of humanity and the Mediterranean Race, as alternatives to 'Teutonic' Aryanism. He was developing the foundation of his bold non-Darwinian, non-linear, polygenic, multi-variant perspective on the evolution of the human species and their division into separate racial groups following their own paths of progression or regression. But these were the years too of his dark and despairing Lombrosian phase, when he wrote numerous works on human variegation and inequality and mental illness and delinquency. As a degenerationist, Sergi produced, for example, his Le degenerazioni umane (Human Degenerations), a bleak homage to Morel and Lombroso, which supported the Spencerian anti-reformist line that all public and private institutions of relief and any kind of 'socialistic or humanitarian forms of altruism' and social welfare must be 'severely limited and selective' because 'the protection of the unfit only leads to greater degeneration over generations'. Philanthropists and do-gooders from the Left, Sergi argued forcefully throughout the text, were wasting their money opening night shelters, soup kitchens, and mothers' homes for 'prostitutes, beggars, alcoholics, cheaters, swindlers and frauds' with a congenitally and irremediably 'inferior animality'.22

How Italy got to such a perilous state was the central question which he sought to answer. Sergi's particular 'cultural despair' over the proliferation of degeneracy of all kinds found expression at this time in works which blamed liberal governance for causing, he lamented, all 'civil and social Progress to cease. ${ }^{23}$ Sergi was not a pacifist so much as he was a pessimist. ${ }^{24} \mathrm{He}$ was a selfconfessed apolitical man of neither the right nor the left. He possessed no political affiliation of any kind and had no history, unusual for a man of his generation and age, of ever having participated in politics: 'I belong to no one', he claimed of himself. ${ }^{25}$ But his political perspective was distilled through

positivist thinking: R. Young. 'The Development of Herbert Spencer's Concept of Evolution.' In Actes du XIe Congrès International d'Histoire des Sciences. Warsaw: Ossolineum, 1967, 273-78, 277 .

22) G. Sergi. Le degenerazioni umane. Milano: Dumolard, 1889. Quotes on pp. 182, 202, 206 and 226; see too his La stratificazione del carattere e la delinquenza. Milano: Dumolard, 1883, and: La degenerazione del carattere. Roma, 1888.

23) G. Sergi. 'Come sono decadute le nazioni latine.' Nuova antologia di scienze, lettere, ed arti, clxvi (August, 1899), 385-99, 397.

24) L. Tedesco. "For a Healthy, Peace-Loving, and Hardworking Race': Anthropology and Eugenics in the Writings of Giuseppe Sergi.' Modern Italy 16 (2011) 1, 51-65. Sergi's 'pacifism' was not so straightforward or simple as this work suggests. Sergi's point of critique was not imperialism as such, but rather the failure of repeated campaigns, which he saw as a symptom of the political invalidism of the ruling class.

25) G. Sergi. La decadenza delle nazioni latine. Torino : Bocca, 1900, v. 
Spencerism. Just as Spencer argued in Social Statics, Sergi believed very strongly that the state had a duty to foster continual progress. ${ }^{26}$ In Sergi's opinion, liberal governance lacked moral authority or political legitimacy precisely because it had failed to do this and had broken its social contract. One of his most important works at this time, La decadenza delle nazioni latine (The Decadence of the Latin Nations), made this position very clear. Sergi blamed the governing classes for having caused a 'precocious decadence' by pursuing 'ridiculous' expeditions in Assab and Massowa, both pathetic attempts to assert 'national adulthood'. The traumatic 'disillusionments' suffered should have awakened Italy to the harsh reality of its 'natural inferiority amongst mature nations'. The staggering defeat of the Italian army at Adawa in March 1895 by Ethiopian chieftains caused the collapse of Cripsi's ineffectual government and put a humiliating end to Italy's ambitions in East Africa. These symptoms of the decadence of the 'Latin race' confirmed Italy's 'impotence' in world affairs. 'Shamed and puny', Sergi stated, Italy had consistently blundered in colonial adventures. Crispi had 'pathetically sought to snatch the bare bones discarded by the French, the Germans, and, above all, the British'. Expensive and unprofitable colonial expeditions showed up the deficiencies of Italy as a commercial and military power and were unmistakable signs of the 'inherent political invalidism and cretinism' of the nation's leaders. ${ }^{27}$ This work was a rancorous and bitter critique of the liberal political system and what Sergi perceived as its catastrophic record of failures.

Nonetheless, after the turn of the new century, Sergi's defeatism gave way to a growing optimism about the possibility of what he called a 'resurrection' of the nation. Even as Italy moved into a new progressive era under Giolitti, Sergi never regained faith in the liberal creed. However, he abandoned the constricting Lombrosian framework, which had thrust him into what he called an 'abyss' of despondency about the possibility of ever halting the degradation of human society for which he held liberalism singularly accountable. He embraced a new doctrine of scientism in the first instance and, then, one of its twentieth-century's most important manifestations, eugenics, on the eve of the First World War. Whilst he continued to shun politics, he explained, he was first and foremost a 'moderne', a modernist who re-discovered, after a prolonged post-Risorgimento malaise, a belief in what he called 'the new idea'. He explained his conversion in these terms: 'We Italians are like certain kinds of fish who have their eyes pinned on their dorsal fins and are permanently looking backwards not forwards; if we move forwards, it is by chance and not choice, and is, no doubt, caused by some gravitational pull or a push from

26) H. Spencer. Social Statics: or, The Conditions essential to Happiness specified, and the First of them Developed. London: Chapman, 1851, chapter 21.

27) La decadenza delle nazioni latine. 126. 
some external force.'28 The celebration of 'Latinism' and Italy as the first amongst 'Latin' nations, for him, was predicated upon a destructive and retrogressive glorification of past achievements. The cornerstone of Latinicity, Catholicism represented the worst of what Sergi considered to be obsolete and decadent; it was a 'moribund institution' at the centre of a 'dead civilization'. Statis, immobility, and decline had to be ended if Italy were to achieve a newfound vitality. He had been searching, he explained, for new 'political ideals' to replace the outmoded ones of history. These, he hoped, would be held in common by all Italians in the coming new age of positive change and betterment. He found the best expression of his newly-found idealism in the captivating credo of 'utopia through reform'. This commitment to the 'nuova idea' consisted, he related, 'in the desire to live better, if not in the present, then definitely in the future'. And, 'science is the future'. Modern science would be able to do what the liberal state had proven unable to do, Sergi believed; it would be able to create a true 'Utopia' on earth. ${ }^{29}$

For Sergi and for many others of his generation, population increase under the direction of science and the state would make this dream of racial utopia a reality. The prewar discourse in Italy which focused on the haunting 'nightmare' of depopulation and degeneration was all about sex and death. The decrease in the birthrate symbolized not just the loss for the nation of potential industry and empire, but also, on a very basic and psychic level, it seemed to call into question, for some of the nation's most distinguished scientists, the masculinity and manhood of Italian men. The reality of a downturn in the number of births from the 188 os emblematized a barren and infecund Italy, which represented the eternal female, now a land sadly left unfertilized by its native sons. Italy was a 'dying' and 'diseased' country in which its 'cribs lay empty' and its 'cemeteries are full', as Mussolini later forcefully argued. ${ }^{30}$ Fears about rising rates of male sexual inadequacy and dysfunction permeated prewar discussions about the underlying causes of demographic decline and intensified as a result of the war and the disturbing revelations concerning the 'virility' of the race which it provoked.

One amongst many, Giuseppe Sergi gave voice to these deeper anxieties about the sexual performance, sexuality, and fertility of Italian males. In works which he wrote after he embraced the new credo of eugenics, Sergi expressed very clearly his belief that the decline in the birthrate was not caused by social factors, such as the use of contraception, but rather by a decrease in the sexual potency and physical vitality of Italians. The purpose of eugenics, he clarified, was to modify the race at the deepest somatic level and, through biological and

28) Ibid. 85-6.

29) Ibid. 83, 307, 326

30) M. S. Quine. Italy's Social Revolution. 131. 
social interventions together, effect continuous, positive changes in human heredity and evolution. ${ }^{31}$ The primary dysgenic action of the war lay, he believed, in the destruction of young and fit males and the adverse effect of this damaging demographic change upon the birthrate. The elimination of the most robust members of the male population, and their replacement by older men, with a diminished fertilizing capacity and a reduced level of physical health and vigour, posed a serious danger to the race. Reproductively unfit fathers would pass on their defective germ-plasm to their children. Age re-distribution within the postwar population would render the next generation more prone to a wide range of transmissible biological disorders, as well as sexual invalidism and reproductive dysfunction of various kinds. The nervous disorders associated with combat stress would also have a deleterious impact upon not just the mental capacities, but also the reproductive organs and sexual functioning of future generations. And the prevalence of venereal disease during times of war was widely known to cause a decrease in fertility. Syphilitics tended to avoid medical treatment due to shame and were hardly the best breeders. But, in the coming postwar period, Sergi maintained, state and society together, under the guiding hand of eugenic science, would, hopefully, begin to reverse the damage caused to the race's reproductive fitness by the hostilities. He advocated the introduction of programmes designed to promote sexual and reproductive health and combat the rising rates of sub-fertility and outright infertility which underlay the declining birthrate. ${ }^{32}$

The male sex is often ignored in discussions of the emergence of a prewar pronatalist discourse. But for many Italian natalists and nationalists, modernity and war exerted an unmistakably emasculating effect upon the male sex as a whole. Italian masculinity appeared to be in full crisis. One of the roles of eugenics was identified as a restitution of the fertility, sexuality, and potency of Italian men. The task of re-sexing Italians was not, of course, limited to men. The aim of protecting Italian 'motherhood' was a major leitmotiv of the new biopolitics. Femininity seemed to be under threat. Soon to become Italy's first professor of comparative racial demography, Franco Savorgnan (1879-1963) studied the negative impact of the war on the nation's population. In a book published in 1918, the bio-statistician and eugenicist blamed high female employment in traditionally male armaments and heavy industries for weakening Italy's progeny. After 1915, the rate of stillbirths rose dramatically as a consequence, he concluded, of the influx of women into factory employment.

31) G. Sergi. Problemi di scienza contemporanea. Torino: Bocca, 1916, 219-220.

32) G. Sergi. 'L'Eugenica dalla biologia alla sociologia.' Rivista di antropologia, xix (1914), 351-79; see too his L'eugenica e la decadenza delle nazioni. Roma : Società italiana per il progresso delle scienze, 1916, 21-30, and his La guerra e la preservazione della nostra stirpe. Roma : Direzione della Nuova antologia, 1917, 65-72. 
The work of mothers outside the home decreased the vigour of the Italian stirps; and changing standards of women's appropriate place forced unnatural cultural and biological adaptations in the female species. Like many of his colleagues, Savorgnan voiced his fears that the Italian woman of the near future would deplore the necessity of childbearing and abhor the constraints of marriage. Under the deleterious impact of war, and modernity more generally, maternal instinct had begun to degenerate, rendering many women 'desexed', 'unfeminine', 'unreproductive' and 'unfit' for motherhood. ${ }^{33}$ Dismay over the future of the family compelled many to believe that modern women had become egotistical, had lost their feminine virtues of self-denial and nurturance, and, most frightening of all, had learned to practice birth control. A sexual revolution causing women to gain increased control over sex and reproduction seemed to threaten the race with extinction. In postwar Italy, many observers felt that the relations between the sexes had to be restored to a 'natural inequality' as a precondition for a restoration of proper biological functioning in men and women and a return to healthy population growth. ${ }^{34}$ The apparent loss of women's procreative instinct and capacities contributed to a formulation of the 'Italian woman' as 'fattrice' (breeder or stud-mare) and the 'Italian mother' as reproducer of the race. The fixation on the presumed loss in the Italian race's sex vigour also led directly to a technologization and medicalization of the female body as a defective organism and reproductive apparatus in need of remedy and repair. Female fertility and the female body became objects of intense public debate, scientific scrutiny, and medical intervention. The specter of racial sterility, so central to the conceptualization of the 'population problem' in Italy, contrasted with the impulses behind these sorts of debates in other countries.

Many eugenic movements outside of Italy focused on the question of racial defilement and aimed to promote laws to 'cleanse' the race of 'poisons', such as mental illness and physical disability. Italian eugenicists, overwhelmingly, saw 'race hygiene' in the form of fertility control as a 'Protestant', 'Anglo-Saxon', 'Nordic' and, ultimately, Nazi invention. The broad consensus view was that types of 'a-sexualization' favoured elsewhere were, for the individual, a denial of the basic human right to reproduce and, for the collectivity, an undesirable measure with little foreseeable biological benefit. In contrast to many of their counterparts in other countries, eugenicists in Italy came to depict Italian racial superiority in terms of an innate sexual prowess that had to be protected

33) F. Savorgnan. La guerra e la popolazione. Bologna: Zanichelli, 1918, 132; see my forthcoming work on the Italian school of bio-economics.

34) G. Mortara. La salute pubblica in Italia durante e dopo la Guerra. Bari : Guis, 1925, 1-2, 9-10, $513-5$. 
and enhanced. The pronatalist, pro-conceptive, and pro-life consensus of sorts that arose within prewar Italian eugenics and bio-science, more broadly, would later be instrumentalized under fascism.

\section{Paolo Mantegazza: Unified Italy's First Sexologist and Fertility Doctor}

During the formative period for Italian eugenics, when a 'Population Problem' of a falling birthrate was first identified, major developments in science and society's understanding of fertility occurred. On 10 February 1880, for example, Leo XIII promulgated his encyclical, 'Arcanum', the first statement by the Vatican in the modern period on 'Christian marriage'. The pope's letter to his bishops had been prompted by the incursions of civil marriage and the threat of legalized divorce in liberal Italy and elsewhere in Catholic Europe. He took the occasion of this important and lengthy discourse to re-affirm the unitive and procreative purpose of sex and marriage. The Pope absolutized the higher moral purpose of the physical act of sexual intercourse. The 'conjugal act' was the foundation of marriage which united a man and woman bodily, spiritually, and emotionally; every sexual act must have a generative potential and must be expressive of married love. Marriage was a sacred institution, founded upon natural law and divinely ordained. Its purpose was the procreation of children, who were defined as a gift from God. Fifty years later, his successor, Pope Pius XI, responded to the Anglican Church's cautious Lambeth Conference statement legitimizing the use of contraception in some circumstances with his famous 'Casti Connubii' of 1930. This proclaimed the 'fundamental law of the conjugal act and conjugal relations' to be the basis of all things and condemned as 'grave sins' birth control and any practice which deviated from this vision of morality and matrimony. ${ }^{35}$ Not until Pope Pius XII's 'Discourse to Those Taking Part in the Fourth International Congress of Catholic Doctors' and his 'Address to Midwives in the Nature of their Profession' in 1949 was there a specific papal pronouncement against artificial insemination. But the hierarchical magisterium's views on sexual ethics were never in any doubt.

Catholic teaching was clear on matters relating to sexual morality: sex, marriage, and reproduction were sacred and inseparable; the innate purpose of sex was procreation and love; any and every 'anti-conceptive practice' was wrong;

35) The 1930 encyclical marked a return to medievalism in the Papacy's condemnation of contraception, abortion, divorce, 'negative' eugenics, as well as science and modernity, more broadly; the pronouncements that no civil authority should ever seek to violate the law of God and Nature by undermining the Catholic Church's supreme authority in matters of a private or sexual nature were defiant. His Holiness asserted that the divine and natural order rested upon the sanctity of marriage, male power, and the 'subjection of the wife' within the family: Casti Connubii: The Papal Encyclicals, 1903-1939. Ed. C. Carlen Ihm. Raleigh: McGrath, 1981, 391-414. 
every sexual act must 'remain open to the transmission of life'. This was the basis of the Church's opposition to masturbation, contraception, sterilization and homosexuality and the grounds for its condemnation of assisted conception in all forms. With its modern, secular, and scientific values, sexology and reproductive medicine posed a direct challenge to the absolutist moral universe of Catholic dogma, one in which papal opinion was considered unfailingly infallible. In the immediate post-unitary period, no single scientist better exemplified this seismic confrontation between two distinct and opposing worldviews than did Paolo Mantegazza (1831-1910), the founder of cultural anthropology in Italy. His father was an eminent judge, but his freethinking mother was a countess who opened the first public nursery and the first professional school for women in unified Italy. While pursuing research in the forests of Paraguay, the young Mantegazza married a beautiful Creole woman and became addicted to the narcotic coca leaf. During Italy's wars of national liberation, he got high on cocaine, fought on the barricades, worked in military hospitals as a newly qualified physician and wrote Fisiologia del Piacere (The Physiology of Pleasure, 1854), the first of his 'love trilogy', which included Fisiologia dell'amore (The Physiology of Love, 1872) and Igiene dell'amore (The Hygiene of Love, 1877). The main premise behind these works was that man was an animal with animal instincts; to deny man his true nature was hypocritical. Whilst he believed in marriage and monogamy as ideals, he was an advocate of divorce and a realist.

Above all, he believed in the importance of sex education, especially for young girls, who, in his opinion, needed to be liberated from ignorance and shame about their sexuality. He was a self-proclaimed modernist and nonconformist who refused to remove his hat and to bow, when introduced to the king, as part of his senatorial work and his role as the nation's leading 'public scientist' on government contract. ${ }^{36}$ When the monarch died, he did not wear a black armband at the funeral in Santa Croce as a protest that Garibaldi, whom he considered to be a national hero, would not be honoured in the same grand way as a 'king or pope'. He aimed, he said, to 'modernize and democratize' both the Italian monarchy and Italian society. ${ }^{37} \mathrm{~A}$ best-selling and high-earning sex writer with a rock and roll lifestyle, Mantegazza faced constant criticism from religious quarters but adulation from his many followers worldwide. Whilst still in his twenties, he established unified Italy's first laboratory of experimental pathology in Pavia in 1860 and, through the work which he conducted there on frogs and other animals, he pushed the biological

36) Università degli studi, Firenze (USF), Museo nazionale di antropologia e etnologia (MNAE), Fondo Mantegazza (FM), letter 853, P. Mantegazza (P. M.) to G. Omboni (G. O.), 3 April 1878. 37) USF, MNAE, FM, letter 844, P. M. to G. O., 9 February 1878. 
understanding of fecundation and inheritance beyond their eighteenthcentury boundaries and became a pioneer of sperm retrieval and artificial fertilization.

He was accused of 'immorality' by 'everyone everywhere', Mantegazza jokingly complained to Giovanni Omboni, professor of geology at the University of Padua and his chief confidante. ${ }^{38}$ Mantegazza's infamy, however, did not hinder his academic or commercial success. Within weeks of its publication, his Gli amori degli uomini (The Sexual Relations of Mankind) sold 10,00o copies and prompted a request from his devotees in the United States that he, as the world leader in sexology, preside over a conference on human sexuality, as well as a lecture tour, which would be widely publicized and open to the general public. ${ }^{39}$ His books in the field of what was branded as 'sexual ethnology' or 'sexual hygiene' were kept in print through numerous, regular editions right up to the 1940 and were translated into many foreign languages, including French, German, English, Serbo-Croat, Hungarian, Spanish, Russian, Polish, Greek and Hebrew. The many leading figures whom he influenced, such as Magnus Hirschfeld and Havelock Ellis, credited Mantegazza with being the most important forerunner of modern sexology and with being the first to study human sexual relations shamelessly and scientifically. Mantegazza prided himself on being a universal 'agony aunt' capable not just of providing medical treatment as a physician, but also help and advice of a more intimate and private nature. He regularly responded to letters from around the world from people asking questions about their sexuality, about masturbation, and about their sex lives with partners; most of these were queries about what was 'normal' or not, but some were also requests for 'cures' for what sufferers themselves described as affective disorders, sexual malfunctioning, and the 'sickness of onanism, ${ }^{40}$ Mantegazza's mission in life was not to preach the gospel of abstinence or stand in judgment of others. The purpose of his science of sexual relations, he stated, was to liberate people from repression. He liked being an iconoclast and took great pleasure from the fact that the Catholic hierarchy and clergy in his own country considered his publications to be works of great obscenity. Nothing made him happier, he related, than 'getting up the noses of priests and prudes'. ${ }^{41}$ Eight months after his beloved wife, Jacoba, died in February 1891, after a very brief illness, he married a countess who was thirty

38) USF, MNAE, FM, letter 1325, P. M. to G. O., 24 December 1885 and response of 1 January 1886.

39) P. Mantegazza. Gli amori degli uomini: Saggio di una etnologia dell'amore, vol. 1. Milano: P. Mantegazza, 1886. USF, MNAE, FM, letter 1338, P. M. to G. O., 2 January 1886 and letter 1343, P. M. to G. O., 6 March 1886.

40) See, for example, USF, MNAE, FM, letter 1177, Anonymous letter to P. M. from Liverpool, 17 August 1884.

41) USF, MNAE, FM, letter 2305, P. M. to G. O., 21 May 1897. 
years younger than he; the following year, when he was sixty-one years old, they had a child, a sister to his already grown children. ${ }^{42}$

Aimed at a wide audience, his published works in sexology were very lucrative for him, and helped fund his travels, as well as his many property and business endeavours. He considered his hounding by the national press, and the constant intrusions into his private life which this entailed, to be a small price to pay for the privileged lifestyle which he shared with his friends and family. ${ }^{43}$ One of his chief aims in life, however, was to help people who wanted children, but were unable to have them, to experience the joys of parenthood. As a physician, his primary interest lay in fertility research and treatment. His fame as a pioneer in this experimental science was worldwide. ${ }^{44}$ The desperately infertile traveled from all over Italy and from Europe and America to seek his help as a specialist in artificial insemination. It brought him pleasure that he 'made' counts and countesses and helped conceive heirs for European royal families. ${ }^{45}$ In his written works, he could be quite poetic and poignant about the reasons why he had chosen this particular field of medicine. The starting point for him, as it was for so many nineteenth-century scientists, was Malthus.

Mantegazza explained that from the start of his career as a scientist and doctor he was driven by the realization that the 'potentially infinite fecundity' of humans envisaged by Malthus was no more than a dream. The harsh reality was that man was actually amongst the least fertile of living creatures. Conception was a real miracle of 'capricious' nature and humans were truly wondrous beings. Women's reproductive lives, for example, spanned no more than 30 years at most, during which an ovum would be released little more than a few hundred times. In each individual cycle, so many factors from both the male and female could impinge upon the potentiality of procreation and hinder the progress of the egg, its union with the sperm, and its implantation and development. Man, he argued, 'does not create the forces of nature', but he could, with the help of science, 'direct them to his advantage'. ${ }^{46}$ For this end, Mantegazza advanced reproductive medicine. His novel use of intra-cervical insemination (ICI - still in use today), which claimed higher success rates than did conventional intra-vaginal methods of injection, especially grabbed

42) USF, MNAE, FM, letter 1973, 7 February 1891; letter 1974, 11 February 1891; letter 2000, 1 November 1891; and letter 2052, 29 September 1892, all P. M. to G. O.

43) For example, he was generous with his money. Mantegazza supplied cocaine to one of his drug-addicted, but poverty-stricken acquaintances in France: USF, MNAE, FM, letter 1450, E. Chesneau to P. M., 18 March 1887 .

44) USF, MNAE, FM, letter 1738, Chevalier to P. M. on his 'experiments on humans in the field of artificial insemination', 20 June 1889 .

45) USF, MNAE, FM, letter 1559, Illegible to P. M., 11 February 1888; letter 1572, C. Mantegazza to P. M., 31 March 1888; letter 1873, E. Marzola to P. M., 1 March 189o; letter 2091, P. M. to G. O, 18 April 1893 .

46) P. Mantegazza. Igiene dell'amore. $1^{\text {th }}$ rev. ed. Firenze, 1903, 201, 216, 218 and 220. 
international attention. Despite the censure and criticism that his fame attracted, he managed to get the word out, sometimes in very clandestine ways. A faux-translation of an Italian publication which did not exist, Mantegazza's De la fécundation artificielle chez la femme revolutionized thinking on the subject. He kept a copy of it tucked secretly away in his own library, which was preserved intact by his heirs. Mantegazza defined this work as an 'operational manual' for practitioners in the field. He knew that his method differed from those of his peers, but his aim was to reproduce as closely as possible under clinical conditions the environment in which natural fertilization took place. For this reason, he favoured ICI, because it replicated the way that semen was deposited at the neck of the cervix during sexual intercourse. $\mathrm{He}$ also advocated the method of inserting semen twice within a cycle, to increase pregnancy rates. Moreover, he controlled the conditions and temperatures of the vagina and sperm. He specified, for example, that 'good' sperm had to be concentrated by removing the 'bad' and cleansed of mucus to be made most fertile. And, he warmed it to $37 \mathrm{c}$ (still the norm). ${ }^{47}$ With its sensitivity to the critical issues of temperature, as well as the lifespan, quality, and nutrient culture of sperm, Mantegazza's method paved the way for such improved techniques of the $1930 \mathrm{~s}$ as the cryo-preservation of samples.

Leon Sosiac, an Argentinian physician and follower of Mantegazza, was well aware of just how radical and innovative this branch of medicine was. $\mathrm{He}$ began his 1890 summative text on the treatment of infertility in Italy and France, the two pioneering and leading countries in this highly controversial sphere of medicine, with a description of 'callogenesis' in humans (from the Greek, meaning 'good breeding', specifically through artificial propagation) as the embodiment of secular and scientific values. For over a millenium, he stated, the Catholic Church has attempted to arrest social progress by imposing chastity upon its priests and imposing marriage upon its faithful. The Church's teachings are based on the notion that procreation is a sacred duty; within this restrictive model, 'families unable to conceive experience desolation'. He argued emphatically: 'Despite what the Church and Jesuits say, it is not always possible to have a child'; in these cases, religion offers no hope beyond sustained prayers for fructification. Artificial insemination in animals and humans was not new, but, with modern techniques, its success rates have increased dramatically since 1790, when the Scottish-born physician, John Hunter, recorded the first successful case of impregnation of a woman by

47) P. Mantegazza. De la fécondation artificielle chez la femme. Charleroi: Piette, 1889 , which claimed to be the translation of an extract from the non-existent Gazetta degli ospidali (sic); 3 , 12-13; I found this in Mantegazza's private collection, housed in the Università degli studi, Firenze, Biblioteca di Scienze, Palazzo Nonfinito, Florence. 
means of a simple syringe. This branch of knowledge, more than most medical specialties, was a true liberating force, aspiring to free individuals from religious dogma and increase human happiness. He described Italy as the 'first among Latin nations' because it appreciated the political and broader importance of fertility to the race. Argentina and other South American countries shared the higher fertility and family culture of their 'Latin' leader, Italy, but had yet to appreciate the true political significance of reproduction and population. The 'Malthusians', he argued, had it all wrong. Italy realized that it needed to reverse its declining birthrate because the only way that a country could acquire 'hegemony' in the New World Order of industry and empire was through procreation. The 'fecundity of a people' determined 'the power and greatness of a nation: 48

Sosiac defined callogenesis as the 'art' of producing healthy and beautiful babies when biology failed. Many women, he explained, were not actually made as nature intended. Common causes of infertility in women were manifold and complex: excessive acidity or alkalinity of the vagina and body, any atresia or other physical abnormality of the womb, recurring miscarriage, uterine ulcerations or growths from endometriosis or other diseases, irregularities in menstruation, pelvic neuralgia or problems with the Fallopian tubes (absence, blockage, or inflammation) could all limit a woman's chances of becoming a mother. Sosiac did not hesitate to put men under focus too in the very first chapter of his book. He described male fertility as a complicated balance of different, and sometimes opposing forces relating to both mind and body. There were relatively easily remediable causes of impotence and 'penile defect' that were responsive to psychological therapy or behaviourial modification; these included sexual abstinence, an excess of sex, fear and anxiety about performance, an incapacity to reach orgasms and a lack of trust or intimacy in one's relationship. The physician had to address the fact that male sexuality was predisposed to aggression, as prepotency could lead to a tendency towards premature ejaculation. More intractable were conditions with an organic basis. The role of the fertility doctor in the first instance was to diagnose whether some physical abnormality of the penis or a general diseased state of the mind or body lay at the root of male infertility. Many of the physiological problems leading to this disorder were also treatable. For example, common anatomical abnormalities of the urethra, testicles, or penis itself could be corrected through surgery. It is possible, he explained, to enlarge surgically with a very simple, safe, and successful procedure the aperture to the penis, in order to allow a free flow of seminal fluid. And when surgical

48) L. Sosiac. La sterilità soppressa in ambo I sessi: Fecondazione artificiale secondo I metodi dei professori Paolo Mantegazza e J. Gérard. Milano: Bietti, 189o, 2-3. 
solutions were unavailable, such as in cases involving, most commonly, impotence, but not sterility, procreation was often still possible, since the sperm could be extracted. In this regard, size, for example, did matter when it came to reproduction, as any 'extremity of smallness or largeness of the penis' could impede penetration and insemination. One of the most exciting aspects of this emerging field of reproductive medicine, he stated, had to do with the future of research into sperm and the possibilities that it promised for the treatment of a whole host of 'anomalies' that were presently incurable. Doctors routinely studied the vibrant activity of the zoosperm under a microscope and, since the 186os, largely due to Mantegazza, have understood the importance of sperm motility and count for fertility. But, at the moment, medical knowledge was great, but biotechnology limited, so some problems could not always be corrected. When it came to the treatment of deficiencies in sperm production and quality, there was not very much that medical science could currently offer the patient other than lifestyle and nutritional advice. Amongst a range of options in this department, cold baths, regular massage, and the wearing of loose, unrestrictive clothing to stimulate sperm and physical exercise and the limitation of alcohol consumption to improve overall health could all have positive effects. Some herbs, spices, and essential oils, moreover, improved the chances of conception, while a diet rich in protein fortified the sperm. But, even in the future, medical science would probably never be able to treat some conditions resulting in infertility. Alcohol abuse, for example, was a chronic disease state leading to irreversible damage to the gastro-enterological and reproductive systems. And the effects of age would never be avoidable. ${ }^{49}$

As these specialists realized, conception was a risky and uncertain endeavour. By the end of the nineteenth century, medicine was beginning to have some success in its attempt to correct nature's failings in human fertility. Things had come a long way since 1780 , when Lazzaro Spallanzani, an ordained priest from Modena, became the first scientist to devise and use successfully a technique of artificial insemination on animals (a dog). ${ }^{50}$ But they also had some way to go before Spallanzani's method of in vitro fertilization, which he did in frogs, would be replicated in humans (the first 'test-tube' baby born in 1978). Under the influence of new developments in endocrinology, reproscience and the treatments that it engendered would change enormously in the twentieth century. Mantegazza's generation sought to tamper with the making of life at the point of fertilization. But, the new endocrinologists

49) Ibid. 10-13, 18-21, and 115-18 and part 3, chapter 2.

50) G. Pancaldi. La generazione spontanea nella prima ricerche dello Spallanzani. Pisa, 1972; L. Van Speybroeck, D. de Waele, and G. Van de Vijver. 'Close Connections between Epigenesis, Preformationism, and Self-Organization.' Annals of the New York Academy of Sciences, 981 (2002), 7-49. 
aspired to nothing less than to 're-craft' or remake humans, in their biological totality, in order to increase their reproductive potential and improve their reproductive behaviour.

\section{Making Sex into a Science}

After Mantegazza's day, biomedicine shifted from an anatomical to a chemical understanding of the nature of the body, sex, reproduction and gender. During the so-called 'Age of Internal Secretions', the discovery of the sex glands by Hippocratic humoral medicine 'pushed medical thinking in bold new directions'. ${ }^{51}$ Human beings came to be seen as embodying physical and psychological characteristics of sexual difference; and masculinity and femininity came to be seen as malleable and, therefore, subject to conscious and directional engineering or manipulation by experts in the new emerging science of endocrinology. By the early 2oth century, the new physiology sought mastery over the internal bodily mechanisms - the hormones secreted by the sex glands. Physiologists believed that these solely determined sexual characteristics in humans and profoundly influenced the entire body, mind, and behaviour of men and women. Brought about by the rise of glandular science, the biologization and chemicalization of sexual differentiation and sexuality was accompanied in Italy by the advent of a fascist dictatorship intent upon politicizing, colonizing, and mobilizing the hitherto private domain of sex and reproduction.

These developments are best exemplified by the work of Nicola Pende (18801970), who founded the Italian school of endocrinology and made it into a discipline quite self-consciously different from those in Germany and America, two other countries where the new science also had a huge impact. Better known because of the controversies surrounding the infamous 1938 'Manifesto of the Italian Race', he was, before the fascist period, a world-class scientist with a distinguished career in medicine, having already begun the pioneering research on diabetes that would bring him repeatedly into consideration for the Nobel Prize that eventually went to the Argentinian physiologist, Bernard Houssey, in $1947 .{ }^{52}$ Pende was the scientist, in fact, who coined the

51) C. Sengoopta. The Most Secret Quintessence of Life: Sex, Glands, and Hormones, 1850-1950. Chicago: University of Chicago Press, 2006, 2; A. Fausto-Sterling. Sexing the Body: Gender Politics and the Construction of Sexuality. New York: Basic Books, 2000; The English physiologist, Ernest Starling, was the first to introduce in 1905 the term 'hormone' (from the Greek, meaning to put into motion).

52) In 1997, the Italian television network, Rai Due, broadcast a documentary entitled 'Caso Pende', made by Giovanni Minoli. This re-visited the old controversy surrounding the question of whether Pende had actually given his consent to the appearance of his name as one of the 
term 'endocrinology' in 1909 in the first place. And, as the leading figure within this growing field in Italy, he was responsible for defining its identity and purpose. In America, endocrinologists were largely focused on the search for a hormonal birth control drug, whilst in Germany, they were mainly in pursuit of a simple, but effective means of hormonal sterilization. ${ }^{53}$ In Italy, the exclusive preoccupation lay with conception rather than contraception. The singular objective was the search for the means by which to enhance reproductive fitness and human fertility. Pende articulated this aim through his science of 'biotypology', the inspiration behind William H. Sheldon's grand 'Somatotyping Project' of the 1940 and 1950 os. $^{54}$ For Pende, endocrinology was the study of the hormones, which, as 'chemical messengers', controlled the body's regulatory system; he saw hormones as carriers of information from the brain to every organ and cell within the body. They guaranteed the functional unity of the whole organism and regulated the central nervous and immune systems. Hormonal imbalances resulted in sub-standard ill-health and a fully-fledged disease state. Biotypology was predicated on the notion that each individual was a product of a combination of hormonal, constitutional, hereditary and environmental factors. Though based on the holistic medical approach's idea of the absolute originality of each human being, biotypology sought to classify people according to shared somatic traits and to identify common 'biotypes' and the 'typical' bodily functions and behaviours associated with them. Pende's biotypology was, perhaps, the most extreme form of biological determinism

signatories (so-called 'I Dieci' or 'The Ten') of the manifesto, which first appeared in print in the Giornale d'Italia on 14 July 1938. In brief, Pende claimed to his death that he had never done so, but even his supporters accepted that the documentary proof was inconclusive - there was no damning 'Hitler order' as such, since an authenticated copy in manuscript form, with actual signatures did not exist; but neither was there the written condemnation of the manifesto, which Pende claimed that he had penned and published in September 1938. In any event, Pende was formally absolved of any crime, when large segments of the Jewish community came to his defence and argued that he had actually saved Jews in the final stages of the war, by hiding them in his clinic. Despite the official absolution, Pende's post-war career suffered because of the controversy. He was repeatedly promised a Nobel Prize (on one occasion, his award of it was actually announced, in his presence, at a state dinner held by the Swiss monarch and then quickly withdrawn). It is important to note a certain persistent blindness and silence about racism in Italian culture. Gini, for example, continued to enjoy huge acclaim in the post-war period, despite his life-long racism, contempt for 'primitive' African races, his fierce opposition to the movement for anti-racism within anthropology and his criticisms of the civil rights movement in the United States. F. Cassata. Building the New Man. chapter 7. Scholars worldwide await the day when the principle of academic freedom is restored and the Pende private archives, which are currently being withheld from public access, are finally open to all.

53) R. Dose. 'The World League for Sexual Reform: Some Possible Approaches.' Journal of the History of Sexuality, 12 (2003) 1, 1-15, 10.

54) P. Vertinsky. 'Embodying Normalcy: Anthropometry and the Long Arm of William H. Sheldon's Somatotyping project.' Journal of Sport History, 29 (2002) 1, 95-133. 
known to twentieth-century eugenic science, as well as an extreme example of the social constructedness, historicity, and sociality of gender and sex.

The supposition was that the sexual differences between men and women were profound, as revealed in the sex hormones (the assumption was that men and women did not share the same sex hormones), and that these were inscribed in the male and female body/biotype, not just in the testes, ovaries, breasts or genitalia, but also in general external morphology. Body/biotype determined biological sex; body/biotype also determined both mental faculties and behavioural patterns - the attributes of social gender. The presumed biological divides between men and women embedded in biotypological models are, of course, cultural constructions along 'traditional' gender dichotomies. But biotypology also proposed a new ontology of sex difference in which the practitioner, who was a clinician and a researcher, would be able to control the pathways that an individual traversed towards socio-biological maleness and femaleness. Sex difference was a 'natural' 'fact', but it was also an experimental tool of bio-medicine and bio-science; biotypology aimed to direct human development ever closer towards the attainment of perfection. This ideal was envisaged by Pende and his many followers in Italy as a state of perfect internal bodily symmetry and balance expressed as heightened masculinity and femininity and virility and fertility. Pende married biotypology with the science of 'orthogenesis', an extreme form of Lamarckism, based on the belief in the biological betterment of the body through variations in diet, nutrition, sport, upbringing and environment. ${ }^{55}$ Sex difference was found in the body, but bodies could be socialized in such a way that biology could be altered scientifically. The overwhelming interest of Pende's orthogenetical biotypology was to encourage the advancement of reproductive technologies and methods of social engineering to boost the already proudly proclaimed 'hyperfecundity' of the Italian race incrementally, beginning with each and every individual.

\section{The Ascendancy of Biotypology}

In a work published in 1922, Pende coined the term 'biotypology' for the first time. ${ }^{56}$ Though sometimes mistakenly portrayed as a leading figure

55) See E. Schreider. 'L'École biotypologique Italienne: Tendances et methods.' Bulletin de la Société de Biotypologie, I (December, 1932), 64-97; M. Barbera. Ortogenesi e biotypologia. Roma, 1943 , on the quest for adaptations of the human body in definite and predetermined directions. For the impact on sports medicine, see: G. Gori. Italian Fascism and the Female Body: Sport, Submissive Women and Strong Mothers. London: Routledge, 2004, chapter 4, esp. 77-81.

56) N. Pende. Le debolezze di costituzione. $2^{\text {nd }}$ ed. Roma: Libr. di scienze e lettere, 1928, 13-15. 
within the constitutional 'school' of socio-biological thought, Pende was himself quick to point out the differences between his new science and conventional approaches. ${ }^{57} \mathrm{He}$ defined biotypology as the science 'of the architecture and engineering of the individual human body'.58 Constitutionalism in other countries, and even in the work of his great mentors, Achille De Giovanni and Giacinto Viola, in Italy, focused on human crania and skeletons - the dead concreta. Pendean biotipologia did not examine genotype alone. Rather it studied phenotype, consisting of the living matter, not the bones, of human beings. Pende's biotypology claimed to be the ultimate 'total' and, therefore, 'totalitarian' and 'fascist' science, because it examined the totality of human beings, represented in their physiology, psychology, and consciousness and considered the effects of the biochemical interaction of tissues with hormones, diet, nutrition and lifestyle and the actions of environment upon heredity. Moreover, it evaluated each person individually as a unique organism, but also, using Giuseppe Sergi's system of classification, it uncovered the characteristics common not just to distinct biotypes, but also to each of the races. Pende took pleasure from the fact that his influence was worldwide. Scientists and doctors in many different nations were following his method. Argentina, Brazil, Uruguay, France and Palestine all founded societies of human biotypology in the 1930s; he had many devotees in Portugal, Israel, and France. The Romanians followed his Italian 'school' very closely, he claimed, and even named an orthogenetic museum in the University of Cluj after him. Moreover, they used biotypological techniques in medical fields, like surgery. His influence was most profound, he believed, in 'brother' 'Latin' nations, where long traditions of Lamarkism had bequeathed a predisposition towards this most dynamic and environmentalist theory of human evolution and change. 'True' biotypology, he believed, hardly existed in the 'Nordic' and 'Anglo-Saxon' worlds. In England, it was completely unknown. In America, his devoted follower, George Draper, claimed to be a biotypologist and even founded a specialized clinic there. But, not only did the Americans show no originality in their use of biotypology, Pende maintained, but also they were so rigidly focused upon identifying the single biotype of the 'asthenic' within the general population that they were completely blind to the wider therapeutic implications of this new biomedicine. In Germany, too, the curative purpose of biotypology and its huge potential were largely ignored by the psychiatrists who dominated this field and wished to use it to help wipe out 'defects', like

57) For one such misinterpretation, see: E. D. Monachesi. 'Trends in Criminological Research in Italy.' American Sociological Review, 1 (1936) 3, 396-406, 398-9.

58) Le debolezze di costituzione, 215-20; quote in N. Pende. Trattato di biotipologia umana individuale e sociale con applicazione alla medicina preventive, alla clinica, alla politica biologica, alla sociologia. Milano: Vallardi, 1939, 1. 
schizophrenia and manic depression. With their obsession with eliminating psychiatric disorders, Pende felt, the Americans and Germans applied his methods and classification mainly to promote the cause of the large-scale biomonitoring of society through epidemiology and biometrics. Their aim was to diagnose mental illness in order to segregate, sterilize, or euthanize the defective. ${ }^{59}$

But what interested Pende and his followers in Italy was the promise that biotypology provided to help prevent and treat a whole range of physical and mental diseases, through the identification of overall 'potentiality' or 'risk' factors, within familial, individual, and racial history, biotype, and hereditary endowment, and the formulation of individualized therapies based on the whole body and personality. Moreover, biotypology could promote general health and wellbeing, as well as assist in the management of all psycho-sexual-somatic problems associated with fertility, aging, and longevity. By pioneering the concept of an integrative medicine, drawing upon drug and hormone-based treatments, as well as more naturopathic approaches, and such new fields as geriatrics, Pende extended the reach of biotypology beyond existing medico-social frontiers. He also aimed to expand modern medicine's diagnostic, preventative, and curative capabilities. An essential component of this ambitious plan was his skilful positioning of biotypology as the premier eugenic and fascist science in interwar Italy. In the 1930s, Italian eugenics, along with the biological sciences, social hygiene, and medicine more broadly, were re-founded along biotypological lines. Biotypology also had a wide application in the social sciences, where it caused seismic changes, for example, in demography and sociology. Moroever, it became the cornerstone of 'national medicine' and 'la politica biologica' under fascism, which appropriated the biotypological principle of 'bonifica umana' and made it into the foundational creed for the 'totalitarian' state of the 1930s, its demographic campaign, its aspirations for a 'fascitization' of all Italians through organization and education and its larger plans for the socio-biological engineering of future generations.

Biotypology had such a huge influence partly because it helped Italian eugenics and fascism define themselves in opposition to biopolitics in Britain, America, and Germany. This can be seen readily in the participation of Italian government-sponsored science and medicine in the key international congresses on population in the interwar period. The first of these gatherings was held in Geneva on 29 August to the 3 September 1927. The first World Population Conference was organized by the birth controller Margaret Sanger, and was

59) N. Pende. Trattato di biotipologia umana, 2, 30-35, 41-2, 46. George Draper wrote the forward to Pende's Constitutional Inadequacies: An Introduction to the Study of Abnormal Constitutions. 
devoted to defining population as a 'problem' and perceiving this problem as largely the result of a growing fertility differential between the West and the rest of the world, the geopolitical challenges posed by limits to global food production, distribution, and resources, and overpopulation in poor and 'developing' nations and amongst the 'primitive' races. ${ }^{60}$ The World Union on Population held in Paris on 4-6 July 1928 attracted 35 members from 12 different, mostly European nationalities. The constituent Assembly at the event formally organized national committees, established the International Union for the Scientific Investigation of Population Problems, and asked Corrado Gini (as president of the Italian national delegation) to hold the next such gathering. With Mussolini in the role as honorary president of the proceedings, and Federzoni, Rocco, and Bottai also holding leading positions, Gini hosted the International Congress for Studies on Population from 7-10 September 1931 in Rome, the largest such conference ever held on this topic to date. With fascist officialdom proudly in attendance over what was a major public relations triumph of the regime, over 400 participants from 32 countries in Europe, Asia, North, Central, and South America, Africa and the Middle East listened to 289 papers and reports, which were eventually published in over 5,500 pages of text in ten volumes dedicated to eight major themes, from biology and eugenics to anthropology and geography and biotypology and sociology. ${ }^{61}$ In his opening address, Gini made it absolutely clear that his intention and that of the government and the medico-scientific community which he represented was to overturn once and for all the misconceived Malthusian assumptions and biases of the so-called 'Population Problem' as it was constructed by the Americans, the British, the Germans and 'co-opted' members of the intelligentsia in the colonies which they ruled. ${ }^{62}$ The Italian contributions celebrated the 'positive' and pronatalist consensus within Italian eugenics and fascism and defined prolific people as the most select and desirable group within a biologically well-endowed and gifted Italian race.

\footnotetext{
Philadelphia: Lea \& Febiger, 1928. He considered himself to be Pende's successor. See Draper's Disease and the Man. London: Macmillan, 1930.

60) Proceedings of the World Population Conference Held at Salle Centrale, Geneva, 1928. M. Sanger, ed. London: Edward Arnold \& Co., 1927, 5; Sanger wanted the focus to remain on the issue of the 'grim realities of involuntary motherhood'.

61) Proceedings of the International Congress for Studies on Population (Rome 7-10 September 1931-IX). Ed. C. Gini. Roma: Istituto poligrafico dello stato libreria, 1933-1934.

62) Ibid., vol. 1, 37-45. The German eugenicists present at the meeting 'felt snubbed' at the congress. They also felt acutely that Italian eugenic science and medicine were far more advanced than their own: P. Weindling, 'Summary', presented at the 'Puériculture, Biotypology, and "Latin" Eugenics in Comparative Context' workshop, cited above.
} 
Gini himself was somewhat reluctant to share the limelight with any rival to his position as the government's primary consultant and specialist on matters relating to eugenics and pronatalism. ${ }^{63}$ However, even he had to acknowledge the importance of Pende as the founder of a new science whose influence was global because it embodied the aspiration, so widespread in this age of 'totalitarianism' in thought and practice, that the components of biological race could be altered and improved at will by science and the state. Eugenics was neither monolithic, nor unchanging. The centrality of biotypology to the fully developed eugenics and fascism of the 1930s simply could not be underplayed. Biotypology and the body ideals which it promoted eclipsed Gini's statisticallyoriented demography, which saw people as numbers rather than bodies, grounded the welfarist and reformist biases and agenda of the demographic campaign of the 1920 more firmly in human biology, and came to inspire major departures for both state and society under fascism. These developments revealed the extent to which the fascist dictatorship, in pursuit of its supreme goal of hyperfecundity, was attempting to build a new sociobiological regime and sexual-reproductive order in Italy.

\section{The Science of Hyperfecundity}

Pende understood the attractions of biotypology very well. What the Americans and Germans did not understand, he explained, was that human psychology and physiology were never 'fixed' or 'static'. The eradication of even the smallest physiological 'anomalies' and disease symptoms was possible through biotypological medicine, which worked at the level of every biochemical and hormonal action within the body. Biotypology had already proven, he affirmed, that 'alterations in the hormone balance in women, especially during their reproductive years, can have a profound effect on the body and can completely alter the woman, changing her from one body type to another'. Through biotypology, it was possible with existing medico-technology to create 'a harmonious normality', founded upon 'true robustness in the somatic constitution and psychic make-up of individuals'. Fascism recognized the importance of biology, race, fertility and medicine to the political order and aimed to re-engineer humans through biotypology and orthogenetics. In the present, orthogenetic

\footnotetext{
63) See Gini's address to the First International Congress of Latin Eugenic Societies in which he concedes the pre-eminent position that biotypology held within the consciously 'anti-Nazi' eugenics and fascism of Italy and other 'Latin' countries: C. Gini, 'Biotypologie et eugenique.' In ier Congrès Latin d'Eugénique: Rapport. Féderation Internationale Latine des Sociétés d'Eugénique. Paris, 1937, 200-12; as ever in his work, however, his fixation on the single issue of 'racial interbreeding' dominated the discussion.
} 
biotypology could make people more reproductively fit and more fertile. In the future, it would operate more effectively even at the 'pre-conceptive and intrauterine stage', when the transmission of many diseases took place. ${ }^{64}$ Biotypology appealed because it fulfilled the Darwinian promise of the perfectibility of human beings.

For biotypology and fascism, the perfect human being was hyperfecund in mind, body, and behaviour. The principles of biotypology were that each person should be conceived as a quadrilateral pyramid, with the four sides representing the sum total hereditary patrimony, consisting of morphology, the endocrine system, and moral and intellectual character. The four elements of bio-psychological makeup, comprised of body shape, the neurochemical system, affective traits and intelligence, were subject to the laws of evolution and inheritance, but also responsive to medical and social interventions. Dysfunction in any one part created imbalance or disharmony within the whole biological and mental organism or total body system. These components of constitution and personality, Pende believed, followed the dictates of 'orthogenesis', whereby they evolved in determinate directions through environmental and social pressures. ${ }^{65}$ While the whole function of the human organism was fertility maintenance, according to the dictates of natural selection and the struggle for the survival of the species, the evolution of the individual or the collectivity could proceed in a pathological way, thereby forcing biological and psychological adaptations which rendered the body 'abnormal' or 'sterile'. The aims of Pende's science were to correct these evolutionary mistakes and to insure that the race ceased to produce infertile variants and evolved in the direction of supreme reproductive fitness, defined as hyperfecundity. ${ }^{66}$

Biotypology incorporated into evolutionary biology attitudes about the absolute necessity of sexual differentiation. Like many of his contemporaries, Pende was preoccupied by what he defined as a rising rate of 'female reproductive disorders'. Modern women, he believed, lacked a 'maternal instinct' and had become 'infecund' as a result. To conserve the race, Pende advocated that women undergo a rigorous 'education' from an early age in order to make them more 'feminine' and 'motherly'. To correct the biological tendency towards 'hyponatality', or a decreased physiological capacity for conception

64) N. Pende. Trattato di biotypologia umana individuale e sociale. quotes on 52,623 ; B. Mario. Ifondamenti della biotipologia umana: Il tipo umano medio e le sue varianti: Sistematica introduttiva alla studio delle costituzione e dei rapporti fra costituzione e malattia. Milano: Soc. an. Ist. ed. scientif., 1929, xii-xv, on biotypology's quest to correct 'nature's errors'.

65) N. Pende. Scienza dell'ortogenesi. Bergamo: Istituto italiano d'arti grafiche, 1939, 7-11; 235-8.

66) N. Pende. La biotypologia umana. Palermo, 1924, 911, 23-27; and see his Dalla medicina alla sociologia. Palermo: Cooperativa Gráfica Editrice "Prometeo", 1922, which argued that the social application of endocrinology could improve the race. 
and birth, the 'national problem' of rearing and nurturing the 'future prolific mothers of the race' was recognized by eugenics and fascism to be of critical importance. ${ }^{67}$ Men too were becoming emasculated and de-sexualized as a result of the dysgenic influences of modernity. Pende believed that pronounced muscular, skeletal, mental, hormonal and metabolic differences between men and women determined their separate but complementary sex roles. He classified constitutional variants and their subcategories and attributed specific behavioural patterns to each body type. An alarming number of Italian men, he reckoned, were sexually defective, and most of these unfit males belonged to the 'hypogenital' variety, who exhibited physical characteristics of their abnormality. Hypogenitalism predisposed the body to eunuchoidism because of deficiencies of internal hormonal secretions which caused impaired or incomplete sexual development during adolescence and beyond. Their penises small and sperm scant, these men were unsound in reproductive terms. Because they lacked a 'strong heterosexual physique and temperament', hypogenital men were especially prone to become homosexuals. An 'unnatural' psychological symptom of this disorder, these 'pseudohermaphroditic' men acted more like women and children and were less aggressive than 'normal' men. ${ }^{68}$

For his views on the determinants of masculinity, Pende owed an intellectual debt to the French neurologist, Charles-Édouard Brown-Séquard, who, in 1891, first defined the aims of what later became endocrinology and whose work was translated into Italian in 1894. Concerned with discovering ways to increase 'potency', the French scientist believed internal testicular secretions to be the cause of the 'most noble attributes in man'. A diminishment of sperm production because of old age or infirmity, he recorded in his clinical notes, caused men to become 'less intelligent, honest, ambitious and courageous than real men'.69 In the last decades of his life, Brown-Séquard devoted himself to the problem of 'rejuvenation'. At the age of 74 , he began to inject himself with 'seminal extract', a compound made from the ground-up testicles of dogs and guinea pigs, in order to increase his body's 'nervous force'. After repeated injections of the serum, Brown-Séquard observed an increase in the distance he could propel a jet of urine. The scientist also believed the fluid could be sold commercially as a cure for constipation and senility, as well as a remedy to improve sexual performance, fertility, and virility. ${ }^{70}$ A keen follower of

67) N. Pende. Bonifica umana razionale e biologia politica. Bologna: Cappelli, 1933, 97.

68) N. Pende. 'Costituzione e fecondità.' Proceedings of the International Congress for Studies on Population, vol. 3, 77-103.

69) J. M. D. Olmsted. Charles-Édouard Brown-Séquard: A Nineteenth-Century Neurologist and Endocrinologist. Baltimore: Johns Hopkins Press, 1946, 205-17.

70) L. H. Goizet. Forza e salute: La vita prolungata col metodo Brown-Séquard. $2^{\text {nd }}$. Ed. Milano: Treves, $1894,19-27,36$. 
new-age and alternative therapies, like homeopathy and naturopathy, Pende liked the idea that the body's potency and health could be improved, even in old age, by simple, natural means.

Pende defined what was 'normal' sexuality. He based his views on femininity on a belief that women's personality and physiology derived from a balance of genital, thyreoid, and pituitary gland secretions. When functioning properly, the female organism evolved into a perfect body type characterized by fatty deposits, little muscle, round shoulders, large breasts and heavy thighs. 'Civilized', European women, Pende believed, more frequently possessed disproportionately broad hips than did women from 'primitive' races. The increasingly more common asthenic woman of the post-First World War era, however, was slender and masculine in shape due to an over-activity of thyreoid secretions. These de-sexed, de-natured women were distinguished by specific hypogenital attributes such as small, upright breasts, a flat stomach, boyish thighs and a slight moustache, and these symptoms indicated the biological low fertility or outright sterility of the organism. Hypogenital women were prone to social deviance too. These types of 'New Woman' behaved like men because they could be sexually aggressive, as well as selfish and ambitious. Their tendency towards sexual degeneracy was evidenced in pronounced genital malfunctioning. These 'impaired' and 'inverted' women experienced primary sexual pleasure from clitoral stimulation, rather than penetration. Because they possessed 'hyperevolved vulvae' and 'underdeveloped uteruses', they frequently showed a sexual preference for members of their own sex. Pende also attributed a volatile personality and a low intelligence to the physical condition of 'heterosexual deformity'. ${ }^{71}$ Their total rejection of their 'essential' feminine and maternal 'natures' led, in some cases, to an open embrace of lesbianism, which he defined as a major threat to the race.

Based upon an extreme sexual dimorphism, biotypology sought to circumscribe the confines of normal malehood and femalehood. The biology of sex and gender was 'fixed' by nature, but it was plastic and variable too. There was an ideal dichotomy between the two sexes, but aberrations did occur, which science and medicine would be able to correct. Of equal, if not greater, interest than its exploration of the constituents of the two sexes, this new science sought to diagnose and treat 'borderline', marginal, or liminal human beings. Though the divides between men and women were clearly demarcated, there were many overlappings between the two sexes, Pende believed, and these could throw up a whole number of abnormal biotypes involving 'inter-sexed' or trans-gendered people. ${ }^{72}$ There were, moreover, a range of variations within

71) N. Pende. Constitutional Inadequacies:AnIntroduction to the Study of Abnormal Constitutions. Philadelphia: Lea \& Febiger, 1928, x-xv; 330; 265-69; N. Pende. 'Costituzione e fecondità.' 8o-6.

72) The study and elimination through hormone treatment of 'inter-sexuality' became a major concern of endocrine medicine in the early twentieth century. The rapid and unprecedented 
each sex, which threw up the possibility of people who were markedly 'undersexed' physically and psychologically. The hope was that all these 'abnormalities' in biotype and behaviour, which adversely affected fertility, would be 'corrected' by the new racially motivated medical science promoted actively by fascism.

One of these under-sexed biotypes, for example, comprised men and women with a 'hypopituitary constitution', who showed specific mental and somatic characteristics associated with sexual immaturity and intellectual precocity. Pende described the hypopituitary male as a flabby, effeminate, and slothful somatotype who suffered from a pronounced underdevelopment of the primary sexual organs, a lack of libido, and recurrent and sometimes chronic impotence. ${ }^{73}$ Because of their inadequacies, these men possessed depressive natures and often turned to mental pursuits to compensate for sexual deficiencies. Often intellectuals and radicals, left-wingers and non-conformists, these men were emotional and irritable, as well as critical and disruptive of social order. Hypopituitary women deviated from Pende's norm by presenting masculine physical and mental traits. Abnormal development in this biotype evidenced itself too in an asexual temperament and infertile constitution, resulting often in the repudiation of marriage and the choice of 'spinsterhood' common to this kind of woman. The most striking attribute of the hypopituitary female was their unusual propensity towards intellectual endeavour and rational thought, which Pende considered to be absent in normal women. ${ }^{74}$

The complexity of human sexing and sexuality was revealed in the range of biotypes which Pende uncovered; this made his form of biotypology, focused as it was on the pursuit of super-fertility and the hierarchical classification of human beings in relation to this single trait, unlike any other national variety of this science anywhere in the interwar period. Deficiencies in testicular and ovarian function caused 'hypothyreoid' men and women to be more imaginative than normal people. Excitable and tense, these types were prone to a childish disposition because of lack of mammary and penis development, body hair, and libido. Other biotypes comprised the 'hyperpituitary woman' who exhibited male characteristics, like muscular tone and physical strength.

\footnotetext{
social changes engendered by the war were a major catalyst in this regard, spurring calls for a restoration of the 'normal' sex and gender order: see F. Giannuli. 'Dismorfie endocrine.' Rivista di antropologia: Atti della Società Romana di Antropologia, 21 (1916-1917), 215-234, which contains photographs of the genitalia and bodies of patients at a mental asylum in Rome who were identified as 'female defectives' because of their somatic anomalies, which rendered them more 'masculine' than 'feminine'.

73) Hard male bodies was the hyper-masculine ideal. For a discussion of the 'discursive regime' of 'compulsory heterosexuality' under fascism, see B. Spackman. Fascist Virility: Rhetoric, Ideology, and Social Fantasy in Italy. Minneapolis: University of Minnesota Press, 1996, 34.

74) N. Pende. Bonifica umana razionale e biologia politica. 114-15.
} 
Her extreme upperbody development disturbed her ovarian balance and rendered the system 'unreproductive'. The 'infantile female', a cross between the pure hypothyreoid and hypopituitary types, possessed an overly developed heart and aorta which caused her to be submissive and self-denying. And the brains of 'hyperadult' woman showed congenital abnormalities and lesions which inclined her towards forms of behaviour more typical of a man, such as decisiveness and authoritativeness. According to Pende, the 'normal' male was ostentatiously virile and manly. This biologically superior type was extremely fertile, evidenced by the precocious size of his genitals, a strong sex drive, and the abundance and potency of seminal fluid. 'Hypergenital' man's perfect mate was the 'hyperovarian' woman, who produced more ova than the average female. Though some hyperovarian women had an 'active libido' determined by an 'exaggerated sensitivity of the secondary sexual organs, the breasts and vulva', most possessed a more modest 'feminine' nature reflecting their 'hyperfecundity'. This type of woman bore the physical signs of her primary mission to reproduce the race. The 'prematernal woman' was slim and narrow in her lower body, but these were temporary masculine traits. As she grew into full womanhood, and 'after a long exercise of her biological and social function of bearing and rearing offspring', the 'normal' woman evolved into a 'mature maternal type'. Her hips and breasts enlarged, the maternal biotype exhibited the attributes of motherhood. A 'reproductive apparatus fully adapted to nourish and defend the fruit of her womb', hyperovarian woman was Pende's ideal of femininity. ${ }^{75}$

\section{The New Biology and Biotypology in Action}

Biotypology cast the feminine and masculine body as potentially malfunctioning organisms in reproductive terms, ones that could be corrupted by evolution or society, but which were correctible through socio-biological therapy. Under Pende's skillful direction, biotypology became a key component of the transforming of sex into a discourse and the creation of a modern health regime devoted to the propagation and protection of the 'national body'. In clinical practice, social policy, and science and society more generally, its impact was widespread in the interwar years. Pende's influence proliferated and provoked a great deal of discussion in medical, scientific, and government circles and helped push fascist and eugenic biopolitics in new directions. Italian fascism and eugenics would be very receptive to Pende's ideas about biopolitics.

\footnotetext{
75) 'Costituzione e fecondità. 84-86; Trattato di biotypologia umana. 103-28.
} 
On 15 March 1919, the eugenics society was re-founded as Società Italiana di Genetica ed Eugenica (SIGE; Italian Society of Genetics and Eugenics) at Rome University and placed under the presidency of Ernesto Pestalozza (1860-1934), the distinguished professor of obstetrics and gynaecology, puericulturist, and social reformer, the vice-presidency of Corrado Gini, the world famous demographer and statistician, and the secretaryship of Cesare Artom (1879-1934), a celebrated zoologist and professor of comparative anatomy. The reformation reflected the desire to detach Italian eugenics from NicoluccianMantegazzan-Sergian racial anthropology, its original source, and to make the biological sciences more systematically the basis of eugenic research in Italy. While they determined to maintain the links between anthropology and the social sciences and eugenics, the central committee and members of SIGE vowed to promote the progress of radical, new scientific endeavours in the fields of biomedicine, zoology, botany and biology, which, they believed, would unlock the mysteries of human heredity. ${ }^{76}$ Artom himself explained the importance of the name change and the new outlook for SIGE. Nineteenth-century anthropology had given Italian eugenics from the start an appreciation of the importance of biological race. Eugenics everywhere was first and foremost Galtonian and Darwinian in conception, he stated; the quest for the means to promote the beneficial evolution of the race always was and always would be the aim of eugenics. The search for the best forms of social intervention to improve the race would continue in the postwar period; but, eugenics had to keep up with scientific advancements and move with the times. Artom stressed that 'eugenics and genetics must now work together to answer the question of whether human beings can actually be improved'. He was quite clear, however, that 'eugenics must follow genetics', and not the other way around, 'for genetics is the key to heredity' 77

Vincenzo Giuffrida-Ruggeri (1872-1922), who was elected to the central committee of SIGE and asked to lead eugenic research in the field of anthropology, affirmed the continued commitment of the society to social eugenics, but explained that 'acting on the environment alone is not enough'. The environment was 'not omnipotent'; eugenics needed to operate at the level of human biology and the individual body if the 'true potentiality of the Italian race' were ever to be realized and the wider goal of the betterment of humankind were ever to be achieved. The real challenge, he argued, was for Italian eugenics to continue to follow its own path towards racial utopia within the international movement. Italian eugenics epitomized the reality that a

76) 'Statuto della SIGE', and deliberations made at the first meeting, on 19 April 1919, in SIGE, Atti della Società Italiana di Genetica ed Eugenica, fascicolo I (1920), 4-8.

77) C. Artom. 'Per gli studi di genetica ed eugenica.' Ibid. 11-4. 
balance between 'the social' and 'the biological' could and should be struck. Indeed, Giuffrida-Ruggeri formulated and expounded what was Italian eugenics' first formal statement of support for the adoption of a programme of genetic engineering or the socio-biological re-crafting of humans on a grand scale. Within world eugenics, he stated, time was being wasted arguing about such inconsequential matters as marriage certificates, when the infinitesimal universe of chromosomes had the real answers to the secrets of heredity and evolution. Modern genetics and biomedical sciences, he stated, would render most, if not all of the current platform of 'negative' eugenics entirely and universally useless and unnecessary. In the future, Giuffrida-Ruggeri stated, the social application of a eugenics founded upon genetics would eradicate many diseases endangering the race and, thereby, eliminate the need for the 'cruel' and 'barbaric' measures of sterilization and euthanasia advocated by the likes of Richet and his many followers. ${ }^{78}$ For the Italian brand of a more modern and forward-thinking, genetically-minded science of race betterment, the remaking of humans at the level of each cell within the body, at the point of conception, and continuously throughout the life of the individual was a far grander and nobler mission than was the 'unscientific' pursuit of a negative eugenics of dubious intent and worth.

The very first conference of the newly formed Italian Genetics and Eugenics Society was held in Milan in 1924, with the co-operation of the Royal Hygiene Society. During his inaugural address to the assembled, Leonard Darwin, speaking in his capacity as president of the International Eugenics Commission and as president of the English Eugenics Education Society, echoed some of these sentiments when he noted that in the postwar period, eugenics had entered a new phase. This was marked by progress in some countries, like Italy, where the impact of eugenics upon politics was already great, and by a reawakening of interest in its first principles, devised by Galton. The most important of these founding and fundamental tenets was the notion that the struggle for the betterment of humanity had to begin with human biology, which eugenics sought to govern. ${ }^{79}$ Many of the ninety speakers at the congress affirmed this commitment repeatedly. The purpose of the society's name change was to represent the core idea of the new 'eu-genetics': the dictate that eugenics must follow genetics and must operate at the level of the human body, as well as that of society. For this reason, Alessandro Ghigi (1875-1970), a zoologist based in Bologna, related that zoology and botany would become a main focus of the

78) V. Giuffrida-Ruggeri. 'Il problema fondamentale dell'eugenica.' Ibid. 32-6.

79) Darwin's lecture in Società Italiana di Eugenetica Sociale (SIES), Atti del primo congresso italiano di eugenetica sociale, promosso dalla società italiana di genetica e di eugenica e dalla $r$. società d'igiene, Milano, 20-23 settembre, 1924. Roma, 1927, xii-xiv. 
new eugenics because animal and plant research would expand genetical knowledge and thereby assist the eugenical mission. ${ }^{80}$ Even at this early date, which was years before Italy's first Centre for the Study of Human Genetics was founded, in 1941, within Rome University's Institute of Biology and Zoology, part of the medical faculty, many Italian eugenic scientists saw conception as the key to racial progress and the need to control both it and its 'product' as a major objective of their endeavours. ${ }^{81}$

At the pivotal 1924 meeting, for example, the importance of understanding heredity through the process of fertilization was emphasized. The entire conference was framed around an exploration of medical ethics and was highlighted by the weighty contribution of Friar Agostino Gemelli (1878-1959), who was chancellor of the Catholic University of the Sacred Heart in Milan, a physician, and an experimental psychologist. His critical importance to eugenics had already been firmly established in his works in human psychology, which moved the study of the mind and the brain closer to later conceptualizations of neuroscience. His complex view of human emotions and mental illness developed in direct antithesis to the anti-curative stance of Lombroso and his 'school'. Gemelli based his belief that even serious affective and mental 'defects' could be cured on his understanding of the total plasticity of the brain. ${ }^{82} \mathrm{He}$ was, of course, also the chief architect and proponent of a very Italian clerical eugenics that bridged the divide between science and religion and made eugenics entirely compatible with Catholicism. His piece not only spoke forcefully against negative eugenics, but also affirmed the notion that eugenics must strive to be a humane 'biogenetics' that was pro-life, equally as committed to the protection of human life and the alleviation of human suffering from disease as it was to answering the biggest question of all: the origin of life itself. ${ }^{83}$ Only one delegate at the conference spoke out in favour of sterilization, which he advocated be introduced for the mentally ill. The strong pro-life thrust of the congress came out in paper after paper, many of which promoted the idea that the pursuit of advancements in biomedicine to improve the human species in desirable ways was a better use of eugenics than the cause of 'anti-conception' and 'anti-life' to which so many foreign eugenicists were devoted. Pestalozza reminded his colleagues, for example, that therapeutic abortion, once so commonplace a treatment for a host of potentially

80) A. Ghigi. 'La teoria della costituzionalità nei suoi rapporti con la dottrina della specie.' Ibid. 111-16.

81) 'Comunicazioni. Genus, 5 (1941) 1, 177.

82) A. Gemelli. L'Enigma della vita e Inuovi orizzonti della biologia: Introduzione allo studio delle scienze biologiche. Firenze: Libreria editrice fiorentina, 1914, vol. 1, 7-8, and vol. 2, chapter 1 on heredity.

83) A. Gemelli. 'Religione ed eugenetica.' SIES. Atti del primo congresso italiano di eugenetica sociale, $53-66$. 
life-threatening conditions, such as pelvic deformity, were becoming exceedingly rare. They were now not necessary even in such serious illnesses as tuberculosis, which posed no risk to the pregnancy or the unborn child. ${ }^{84}$ The congress delegates deliberated at length about their mission statement and subjected a number of issues to the vote, none of which included any negative eugenic measure. While they did not endorse sterilization, they did adopt a resolution calling for better reproduction and better conception as the way forward for their kind of eugenic science. The congress also voted to promote acceptance within government and society of what Ghigi called 'constitutionalism', the precursor to Nicola Pende's biotypology. 85

The fascist regime and its representatives, along with the king, fully supported SIGE's second congress in Rome, which took place in 1929. By then, eugenics had become officially sanctioned as a state science and SIGE and its various affiliated organs had become thoroughly institutionalized through the government funding and sponsorship of chairs, research, exhibitions and events. As dignitaries at the conference explained, fascism recognized the importance of eugenics to the goals of its demographic campaign, which were to foster national education and a race consciousness, awareness of issues of health and hygiene, and racial improvement through welfare and social reform and scientifically controlled fertility increase. The shared imperative of 'quality and quantity', which was identified as the conceptual common ground between eugenics and fascism, was a major theme of that conference. The regime had entrusted eugenics with the important task of managing this vast programme and bold experiment at artificial and accelerated 'evolutionism'. Over 300 delegates, and numerous foreign participants, including Charles B. Davenport, who was president of the international federation of eugenic organizations and director of the Carnegie Foundation's Institute of Genetics, listened to many papers on how applied biomedicine, greater understanding of human constitutions and biotypes, genetics and the scientific control of fertilization, fertility, and reproduction would make the shared vision of eugenics and fascism a reality in the future. ${ }^{86}$ By the time that the third meeting of SIGE took place in Bologna, from 5 to 7 September 1938, under the direction

84) E. Pestalozza. 'Le operazioni operatorie in rapporto all'eugenica.' Atti del primo congresso italiano di eugenetica sociale, $81-5$.

85) A. Ghigi. 'La teoria della constituzionalità nei suoi rapporti con la dottrina delle specie', 111-6 and the resolution in its favour, xli.

86) 'Comitato d'onore'. SIGE. Atti del ii congresso italiano di genetica ed eugenica, proposta dalla società italiana di genetica ed eugenica, Roma, 30 settembre-2 ottobre, 1929. Roma, 1932, 5, which included all the relevant government ministers, senators, as well as the leaders of major fascist social welfare and insurance organizations (such as ONMI, the National Insurance Institute, and the National Invalidity Fund) and government-run commercial and industrial organizations (such as the Fascist General Confederation of Industry); inaugural address by De Marzo, under-secretary at the Ministry of National Education, Ibid. 16-7. 
of Ghigi, now director of the Zoological Institute and rector of the University of Rome, the new genetics and biomedicine completely dominated the proceedings, with two sessions devoted to papers in these fields and only one dedicated to eugenics. ${ }^{87}$

In this environment, Pende's biotypology found a receptive audience because of the potential that his science of sex, vitality, and sexuality had in creating healthy bodies, boosting human fertility, and controlling people's lives from cradle to grave. These aims appealed both to eugenics and fascism. Pende was keen to take advantage of opportunities to promote both his science and his career. In numerous works, he came out in fulsome support of eugenics, the regime, and the demographic campaign. He argued that a fascist dictatorship with heightened regulatory aspirations and increased powers would be able to make the right social adjustments to the sexual and gender order which would ensure that all men and women in the future would fulfill their 'natural' roles and reproduce prolifically. By the end of the 1920s, fascism's efforts to protect the fecundity of the Italian race already included a wide range of social measures, including welfare reforms targeted at mothers and children, insurance benefits aimed at working-class fathers, and others to defend marriage, procreation, and heterosexuality. Pende and his increasingly influential biotypological agenda propounded the view that the dictatorship should also implement a more far-reaching programme of 'political biology' that would, over time, alter positively the biological profile of the Italian race. ${ }^{88}$

A significant component of the expansion of population and race policy into new biomedical arenas that Pende promoted and piloted in the $1930 \mathrm{~s}$ involved efforts to identity and eradicate all illnesses which, from conception onwards, potentially or actually adversely affected fertility. The huge undertaking that he envisaged, and which was being implemented, necessitated a utilization of existing health and welfare resources and institutions, run by public, private, and party agencies, and a development of entirely new forms of care revolving around the wide application of biotypological principles in all branches of medical knowledge and all aspects of clinical practice. For the pathological evolution of each individual to be stopped, an early diagnosis of any increased risk of sterility was crucial. Chronic conditions, such as tuberculosis, venereal disease, alcohol and drug abuse and mental illness, in the adult population were already under government focus as areas of major concern from a racial point of view because they detrimentally affected fertility, the health of a growing fetus, and child welfare. Pende advocated the use of systems of health screening already in place for biotypological data-gathering

87) 'Sommario.' Genus, 3 (1939) 3-4, i-ii.

88) See, for example, his Bonifica umana razionale e biologia politica. Bologna: Cappelli, 1933, chapter 4 . 
and the medical diagnosis of constitutional abnormalities leading to infertility. He recommended to the government that all health professionals coming into contact with the public should be trained in the methods of biotypology and should alert specialists so that, ideally, treatment plans could be begun before fertility was irreparably damaged. The compilation of anthropometric statistics on schoolchildren and the identification of body types with potential diseased states in the clinical setting would make, he argued, a critical contribution to the campaign to protect the sexuality, biology, and fertility of Italians. Once a diagnosis was made, the treatment of physical problems could commence; these included whatever environmental and lifestyle changes were deemed appropriate given the condition of the patient. Research and development in the use of cutting-edge medical therapies were a key component of the new biomedicine that he pioneered. Within his own clinical practice, for example, he used X-Ray 'therapy' as a 'cure' for hypogenitalism in babies. But through endocrinology, the primary focus of biotypology was on the achievement of hormonal balance in adults with the purpose of promoting an increase in hyperfecundity within the general population; he and his followers who practiced medicine offered a range of hormone treatments for problems in sex and reproduction, especially those involving infertility.

Monitoring and controlling the somato-mental development of the young was a major concern of public health initiatives under fascism. Much of the impetus for this came from biotypology. The year 1927, when the dictatorship was formally inaugurated and enshrined in what commentators called its 'eugenic and race programme', also officially marked the launch of a new era of 'totalitarian medicine' befitting a 'totalitarian state and society'. The 'lotta contro adenoidismo' (struggle against adenoidism) was but one facet of this multipronged approach to the problem of safeguarding the fecundity of future generations. According to medical opinion, adenoid hypertrophy was a 'dominant hereditary condition, transmitted from parents to offspring via Mendelian inheritance'. Pende believed that the propensity towards it was caused by ipopituitarismo (the hypopituitarism) because its symptoms, such as a lack of concentration, loss of memory, and sleepiness, were similar to those of the glandular disorder. Though the effects of the illness were relatively mild, one medical expert explained, it was a major concern for the regime from a racial point of view because it disrupted the normal physiological and psychological development of adolescents at a time when the sex hormones were beginning to become activated and could, therefore, have an extremely adverse effect upon fertility. This was potentially a dysgenic and anti-demographic factor of huge proportions since, within Naples alone, where data was being collected from 1927 onwards, as many as $15 \%$ of all school leavers (11,60oo in total) were known to be afflicted in the period up to 1932. Prevention and cure of racial 'sterility' were the lynchpins of the regime's own pronatalist form of 
race hygiene. Drug therapies and, in hard cases, adenoidectomies claimed almost total success in stopping reoccurrences. By instructing all tuberculosis clinics to pick up on the disease, and sending doctors into elementary schools, fascism was implementing throughout the nation a successful policy of 'socio-biological prophylaxis' to protect and enhance racial fecundity ${ }^{89}$ The new holistic doctrine of orthogenetic biotypology also manifested in raised awareness about the importance of good nutrition to reproductive wellness. It inspired, for example, the National Council of Research, a government-run agency for the promotion of science, to sponsor a large-scale, on-going study, beginning in 1933, of the daily diet of the Italians in all provinces and regions and to examine the impact of national variations in nutrition upon the birthrate. Conducted by Alfredo Niceforo (1876-196o), a world-class political economist and Galtonian bio-statistician, who sat on the central committee of the Geneva-based League of Nations' hygiene division, the research results were published regularly in the Quaderni della nutrizione; the data confirmed huge variability by class and locality of patterns of consumption and highlighted the deleterious demographic implications of poor diet upon the racial biotype. ${ }^{90}$

In recognition of biotypology's critical importance to fascism, Mussolini and his education minister, Giovanni Gentile, gave the task of planning its first new 'fascist' university to Pende. In 1925, Pende was formally appointed as the 'Magnificent Rector' of the new Royal University of Benito Mussolini in Bari. Having plundered the coffers of its social security fund for workers to help pay for the new medical faculty there, the first department to be established, the government increasingly invested resources in the biotypological project. After the regime awarded him in 1933 a place for life in the Senate, in thanks for his contribution 'to the race', Pende collaborated closely with Giuseppe Bottai and was able to realize his dream of introducing in all state schools throughout the kingdom the 'biotypology index cards' that documented the biometric development of all children in state schools in fascist Italy. At his Institute of Human Biotypology and Orthogenesis, which he founded in Genoa in 1925 , Pende began to conduct biometric research on women patients. This was targeted at fostering his huge project of 'bonifica umana' (human reclamation or the re-engineering of humans into New Hyperfecund Man and New Hyperfecund Woman); officially recognized as the pre-eminent fascist and eugenic science and a central underpinning of the dictatorship's long-term master plan for Italy, biotypology was thoroughly fascistized, institutionalized, and 'statilized' in the 1930 .

89) A. Della Cioppa. 'Rendiconto e dati statistici della lotta contro l'adenoidismo nelle scuole elem. di Napoli per il quinquennio 1927-1932.' Difesa sociale, 12 (1933) 2, 76-84.

90) Consiglio nazionale delle ricerche.Quaderni della nutrizione: Organo della Commissione per lo studio dei problemi dell'alimentazione. May 1934. 
A key component of this ambition involved planning for the future. In 1938, construction work began in Rome for the new central headquarters of the Institute for 'Bonifica umana' and the Orthogenesis of the Race; this was to be a fully state-run institute and hub of the ever more radical and expansive race and population policy of the regime, which was sought to colonize new spheres in socio-biology. Coordinating and directing the work of other agencies involved in welfare, educational, and health initiatives, such as ONMI, this institute was conceived as a centerpiece of the new biomedical modernity and reproductive racial order promoted by the regime. The government committed itself to funding the building and the running of this key institution. Initially the Pious Institute of the Holy Spirit and the Combined Hospitals of Rome would foot the bill; but over a 30-year period, the government would reimburse these organizations through annual payments from its social fund, which was raised through worker contributions. ${ }^{91}$ Pende wanted to use the project for human reclamation initially to gather empirical data on a nationwide basis on the physiological differences between 'normal' - defined as highly prolific- and 'abnormal'- that is, less fecund - men and women. This work would build on the biotypological research which he had been conducting over the course of his career; in his clinic in Rome, for example, he and his two female assistants had been taking the measurements of the body proportions of all of his patients, and correlating these with their reproductive histories. Eventually, the institute would be responsible for all initiatives in the realm of racial orthogenetical and reproductive bio-medicine and social policy with a procreative and pro-conceptive purpose. This vast application of biotypological principles in all aspects of fascist health care within schools, hospitals, work places and the home would be the perfect culmination of the regime's ever evolving and expanding demographic campaign. The future of this ambitious endeauvour, Pende believed, looked promising. On the basis of the records which he already had, Pende reported that 62 percent of all Italian women were hyperovarian. Less than half that number of British and German women could be deemed hyperfecund, Pende asserted proudly. And most Italian men, he observed, enjoyed a pronounced hypergenital disposition. More fertile and sexual because of their superior constitutions, Italians, he believed, produced a greater number of gametes and a better quality sex cell than did any other race. ${ }^{92}$

91) M. S. Quine. Italy's Social Revolution. 124-8; 'Notiziario.' Difesa sociale, 16 (1938) 7, 675-6;

G. Grossi. Legge e potenza del numero. Bologna : Zanichelli, 1935, 18-21, 57-9.

92) Bonifica umana razionale. 110; 'Costituzione e fecondità.' 75. 


\section{The New Fascist Reproductive Order}

The discoveries of sex science perfectly encapsulated the concerns of Italian society in the interwar years. The representations of the various types of male and female bodies which biotypology produced reflected the social anxieties and political aims of a dictatorship with a pronounced pronatalist agenda. Both science and fascism responded forcefully to the perceived threats to the gender order which modernity, social change, demographic shifts and war had engendered. Italian science in the interwar period developed new hormonebased, biologically essentialist arguments about the normality of clearly defined and restrictive reproductive roles for men and women; these constructions both reinforced and reflected fascism's ideals of masculinity and femininity, men and women, and sex and reproduction. ${ }^{93}$ Within the universe of eugeni-fascist biopolitics, hyperfecundity represented an ideal state of perfect balance and health within the human body and constituted the highest level of biological perfection possible. A regime with such pronounced biological ambitions as the Italian fascist dictatorship defined the attainment of superfertility by individuals and the race as a supreme political duty and political objective.

Studies of the biological and social determinants of sexuality and fertility proliferated throughout the period. Fascism and the biomedicine and racial sciences which it supported had a huge impact as new research agendas grew to dominance. Scientific formulations of sexual difference changed dramatically during the fascist dictatorship in response to political changes. Old stereotypes about men and women were recast in a new medical and scientific vocabulary provided by eugenics and biotypology. The determinants of sex difference, the dangers of biological fertility decline, and the means to promote hyperfecundity became the obsessions of medico-scientific discourses, laboratory study, and clinical practice. Italian scientists in a number of different branches, from the biological to the sociological and statistical sciences, eagerly correlated such diverse physical characteristics as eye colour, physical attractiveness, stature, obesity, length of the nose, time spent at the toilet and a number of other factors, with pycho-sexual development and human fertility. ${ }^{94}$ One study, for example, showed that dress was a 'demographic variable' which directly influenced the birthrate. Elegant and well-groomed women,

\footnotetext{
93) L. Re, 'Fascist Theories of "Woman" and the Construction of Gender.' In Mothers of Invention: Women, Italian Fascism, and Culture. Ed. R. Pickering-Iazzi. Minneapolis: University of Minnesota Press, 1995, 77-99.

94) C. Foà. 'I fattori biologici della diminuzione delle nascite.' CISP. Proceedings of the International Congress for Studies on Population, vol. 2. Roma: Instituto Poligrafico dello Stato, 1934, 957 on the 'lethal factors' which 'frustrate fecundation'.
} 
Carlalberto Grillenzoni argued, possessed a pronounced 'antimaternal nature' and were a detriment to the race. ${ }^{95}$ The assumption was that behaviour had a direct impact upon biology and that bio-medicine and social policy could together force biological adaptations in fertility to occur in the space a few generations. Another took Italian university professors as a sample group to examine the causes of middle-class sterility. This investigation demonstrated that scientists and philosophers were more prone to 'hypofecundity' than those intellectuals who engaged in 'practical' disciplines like architecture or engineering. ${ }^{96}$ The fixation of fascism, eugenics, and biotypology with fertility and gender filtered through into many branches of sciences.

Defined by SIGE as an official branch of eugenics since 1919, Italian zoology was considered an important adjunct science. Breeding experiments in nonhuman species carried out by zoologists were believed to be an important tool of eugenics. In the 1920s, zoology under fascism focused almost exclusively on the study of sex difference and differential fecundity. Zoologists attempted to correlate fertility with the 'outward manifestations of manhood' in frogs, roosters, and pigeons, and they drew human analogies from their observation of lower animal behaviour. Brown-Séquard's influence, for example, could be felt in clinical trials of hormones on frogs which were castrated and then given forms of testicular extract. This research seemed to confirm that frogs had a 'healthy and highly masculine libido, even when made sterile', because they apparently became very aroused and aggressive once injected with the serum. Alessandro Ghigi expanded the reach of biotypology and the genetics of fertility in his zoological investigations. Ghigi's research, like that of other eugenicists who were zoologists or botanists, highlighted the importance of breeding and fertility experiments to the re-founded eugenics of the inter-war period. Italian eugenicists criticized foreign colleagues, especially in Russia and Germany, for testing new hormone therapies and other reproductive technologies on humans, but they considered animal testing, even on other primates, to be morally acceptable. Ghigi's laboratory studies of racial types, fecundity, and hybridism extrapolated human characteristics from the observation of wildlife. He let loose, for example, three male wild roosters from Java amongst native 'Italian' fowl. He reported that the Javanese breed possessed far more pronounced male character traits than ordinary domestic cocks. They 'dominated the hens, separated them from their legitimate husbands, and forced them to copulate'. The foreign birds also took more mates on average than the Italian variety did. This was worrying to him, as

95) S. Grillenzoni. 'I caratteri del fisico e del vestire considerati come fattori demografici.' CISP. Proceedings, vol. 2, 261-69.

96) M. Boldrini and C. Mengarelli. 'Caratteri costituzionali di un gruppo di intellettuali Italiani.' CISP. Proceedings, vol. 3, 269-85. 
he expected results to confirm that the Italian species would be hypermasculine in behaviour and biology. The experiment, however, supported his conviction that interbreeding caused damage as few of the hybrid offspring proved to be fecund. On the strength of these results, Ghigi's major research report concluded that the sexual segregation of the races was necessary to preserve Italian fecundity. ${ }^{97}$

An essential feature of the expansion of state power over the sociobiological domain that took place in the interwar period was the rhetoric and reality of a new regime of controls over the physicality, bodies, and sexuality of men, women, and children. The medical community spotlighted women's endocrine disorders as a major factor behind marital infertility and blamed the sexual mores of the post-war New Woman and the Young Generation for having caused physical damage to the racial constitution. At the top of the list of major factors influencing female fertility, for those specialists concerned with protecting and enhancing the 'natural' sexual order, stood gracility, thinness, excessive sport, career ambition and intellectual pursuits. In party and state organizations, and within society as a whole, the message conveyed was that the young had to be raised in fascist Italy to be 'real' men and 'real' women in order to safeguard the future. The new 'race conscience' under fascism also had an impact upon colonial medicine and policy even before the ItaloAbyssinian war in 1935 and the proclamation of empire in 1936. With Tripoli 'sanitized' and 'civilized' and plague and cholera largely 'conquered' by the early 1930s, the continuing 'racial problem' within the colonies had not just to do with the prevention of the birth of a 'bastard' mixed race. The issue of the 'acclimatamento di razze' (acclimatization of the race) was of paramount importance and involved putting in place a whole system of public health and sanitation to protect the 'superior' Italian stirps from the worst effects of its exposure to living conditions created by 'primitive' and 'inferior' peoples. ${ }^{98}$ The plan of many of fascism's technocrats was for a total mobilization of all institutions in perpetuity and for an extension of the demographic campaign from the mainland to the empire. The incremental, far-ranging, and longterm approach to race hygiene was addressed repeatedly throughout the fascist period; and the hope for an on-going race and population programme was never abandoned. With their promise of socially-engineered biological improvements to the racial endowment, orthogenesis and biotypology gave

97) A. Ghigi, 'Costituzione e fertilità.' CISP Proceedings of the International Congress on Population, vol. 3, 63-75. See too D. L. Hall, 'Biology, Sex Hormones, and Sexism in the 1920s.' The Philosophical Forum, 5 (1973-74) 12, 81-96. See also G. Battara. Fattori psicologici e morali di denatalità. Firenze: Le Monnier, 1935, esp. 102-103 on sex and religion and F. Loffredo. La politica della famiglia. Milano: Bompiani, 1938, 356 on moral factors in depopulation through diminished sex vigour.

98) G. Sangiorgi. 'Per una “conscienza igienica coloniale".' Difesa sociale, 12 (1933) 6, 304-12. 
impetus to fascism's propensity for ambitious, forward thinking and planning. At the $31^{\text {st }}$ Italian Congress of Obstetrics and Gynaecology, for example, which was held from 28 September to 2 October in 1933 in Bari, delegates voted to communicate directly with officials at the National Organization for the Protection of Motherhood and Infancy and to bring authorities in all clinics and hospitals throughout the nation on board. They had spent much of the conference discussing Pende's work on the role of hormones in various aspects of reproduction. Their goal was to influence clinical practice and further research into the preservation and enhancement of fertility.99

The identification of those in need of fertility treatment, doctors recognized, was crucial to the outcome of this grand bio-engineering project. For this reason, government proposals to introduce pre-marital medical screening gained many adherents. The idea of a prenuptial medical examination was different from that of a prenuptial medical certificate in that the first was for the 'control' of disease and the second the banning of marriage after a positive diagnosis. Largely aimed at identifying those with socially and sexually transmitted diseases, like syphilis and tuberculosis, the programme was envisaged as a positive and pronatalist measure. It called for mass screening and the extension nationwide of treatment facilities in order to protect individual and racial health and fertility. ${ }^{100}$ Allied to this goal of utilizing and strengthening existing public health facilities were concrete attempts to create entirely new centres under state direction where all Italians could be treated in an integrative and holistic way for any problems that might impinge negatively upon their fertility. At the initiative of Ercole Cova (1877-1972), the distinguished obstetrician and former pupil of the great Ernesto Pestalozza, the first such fertility clinic opened in 1933 at the Royal Maternity Hospital in Turin, the largest hospital in all of Piedmont. ${ }^{101}$ The regime defined its fertility clinics as the 'core' of its 'struggle against sterility' ('lotta contro la sterilità'). As frontline institutions, they were crucial to the battle: their aim was to identify and treat the causes of infertility; eugenics and biotypology were applied in all aspects of the protocols delivered; through them, advocates explained, the state acquired a 'powerful instrument' for the control and engineering of the biological make-up of the Italian race. In 1933-35, Cova and his colleagues treated there 427 cases of 'involuntary infecundity'. Although Cova personally specialized in surgical interventions, and particularly corrective procedures, most notably when botched, illegal abortions had led to scar tissue and other complications

99) 'Notizie'. Difesa sociale, 12 (1933) 2, 610-11.

100) C. Marciani. 'Il passaporto sanitario - Per la difesa e il potenziamento della razza.' Difesa sociale, 18 (July, 1938) 7, 730-33.

101) T. M. Caffaratto. L'ostetricia, la ginecologia, e la chirurgia in Piemonte, dalle origini ai nostri giorni. Saluzzo: Vitalità, 1973, 355-59. 
preventing pregnancy, other clinicians were beginning to report very favourable results from the new hormone treatments. ${ }^{102}$

Practicing hospital medicine in Reggio Calabria, Michele Surace adopted a holistic and integrative approach that was typical of the Italian 'school' of reproductive medicine since the time of Mantegazza. Surace was no Cova or Pende; he was an 'ordinary' doctor in an 'ordinary' hospital in an 'ordinary' place. Nonetheless, he was actively engaged, at the frontline, in the battle of fascist bio-medicine to discover new repro-technologies and 'conquer' racial sterility. He claimed that even grave hereditary forms of sterility could be cured through his hormone-based drug therapies. His particular specialty was the treatment of abnormalities in menstruation and ovulation. He reported tremendous success in the use of such chemicals as luteinizing and folliclestimulating hormones and thryroid extractions to regulate cycles and restore female fertility. He was also a pioneer of the use of phosphate esters to improve the motility and fertilizing capacity of spermatozoa, treatments which Mantegazza had foreseen and anticipated. In all his tough cases, Surace tried artificial insemination, but advanced a new technique to increase success rates. After implantation, he routinely drew blood from a pregnant woman in her third month of pregnancy and administered by injection a transfusion to the patient. He admitted that he did not understand why, but the treatment to 'activate fecundation' resulted in a 'surprisingly' high number of pregnancies. ${ }^{103}$ The crowning glory for the regime and its countless foot soldiers, like Surace, was the opening in 1936 of the nation's largest fertility treatment facility at the Salsomaggiore spa, resort, and clinic. Funded directly by the state, and managed by the Instituto Nazionale Fascista della Previdenza Sociale (INFPS; National Fascist Institute of Social Provision), the Salsomaggiore Terme centre near Parma provided fertility treatment totally free of charge to those who wanted and needed it. The highest expression of fascist biopolitics in action, the centre represented the largest public health project that Mussolini's dictatorship ever completed. ${ }^{104}$

Repro-medicine under fascism stood at the crossroads. Along with the foot soldiers, there were monumental figures, who were changing entire biomedical paradigms. One such scientist was Giuseppe Montalenti (1904-1990). Ironically, the demographic laws of the fascist regime prevented Italy's most distinguished theorist of experimental 'fecondazione' from taking up a full professorship. The holders of all university chairs in Italy had to be married and,

102) J.Wackmann. 'Incremento demografico e centri contro la sterilità.' Difesa sociale, 15 (1936)1, 332-35.

103) M. Surace. La sterilità della donna nelle sue cause e nella sua cura. Reggio Calabria, 1934, 16-19 et passim.

104) D. Piragine. 'Sterilità, cure termali, politica demografica fascista.' Difesa Sociale, V (December, 1938), 1272-1276. 
preferably, have a large number of children. Unable to fulfill these criteria, Montalenti was initially forced into the secondary division as an assistant lecturer in zoology at the University of Bologna and as the temporary holder of grants in laboratories in France and the United States. The outcome of years of research in developmental zoology, evolutionary sexuality, cytology, embryology, hematology and fertility, his Elementi di genetica (Elements of Genetics) was the first textbook in Italy on the new science and quickly became the definitive summary. ${ }^{105}$ His internationally acclaimed work in biology and reproduction finally won him recognition from the regime. In 1940, Montalenti became Italy's first professor of genetics, in a position created especially for him at the University of Naples. ${ }^{106}$ After the war, his leading position within national and world science strengthened. Amongst other things, he served as general secretary of the International Union of Biological Sciences in 1953-1955 and, in that capacity, was the principal draftsman of their postwar manifesto, the International Biological Programme. ${ }^{107}$ A lifelong Darwinist, largely responsible for the resurgence of Darwinism in Italy in the 1970s, Montalenti took and maintained an evolutionary perspective on problems associated with sex and fertility. His classic statement on the subject was his Problemi di biologia della riproduzione (Problems in the Biology of Reproduction). Published after the fall of fascism, the book is still a product of the time in which it was conceived. The preface defined reproduction, for example, as the most important racial problem of the age. Whilst each individual was destined to die, each race and the human species as a whole were immortal. Reproduction ensured their perpetuity, so it must be examined scientifically and organized politically. In a chapter entitled Crescite et multiplicamini (Grow and Multiply) a pun on Catholic teaching, he betrayed his Mussolinian leanings when he defined the struggle of life as a simple question of producing plentiful offspring to ensure survival. But it was much more than this too. He described the 'force of numbers', a take on Mussolini's famous 'Numbers as Power' dictum, not just as the capacity to reproduce and multiply, but also as a 'force for expansion' in the economy, in the arts and technology, and in empire. ${ }^{108}$

105) G. Montalenti. Elementi di genetica. Bologna: Cappelli, 1939.

106) He continued to hold this position, whilst still based at the Stazione Zoologica Anton Dohm in Naples, the private research foundation, founded in 1872 and funded by the Dohm family and the German government. A reflection of its scientific importance as a world-class research centre in genetic, cellular, and developmental sciences, the Zoological Station was turned into an 'ente morale', or parastate institution in 1924. B. Glass. 'G. Montalenti.' Proceedings of the American Philosophical Society, 137 (1993) 2, 294-98.

107) Accademia Nazionale dei Lincei. 'Giuseppe Montalenti.' In AAVV, Biografie e bibliografie degli Accademici Lincei. Roma: Accademia nazionale dei lincei, 1976, 441-45.

108) G. Montalenti. Problemi di biologia della riproduzione. Verona : Mondadori, 1945, 20, 25-28. 
The work also pointed to the future of human repro-genetics when, Montalenti imagined, the chances of assisted conception would be much increased. Sometime soon, Montalenti anticipated, the geneticist would be able to harvest eggs and sperm from humans, just as the zoologist already did for animals, and then successfully undertake their 'external fertilization in glass' and the implantation of the zygote in the uterus. There was much that could be done already to influence the factors involved in fecundation. When he wrote about sexual selection, Montalenti recounted, Darwin knew nothing about the hormones determining biological sex differences. In 1922, Allen and Doisy identified oestrogen for the first time and, by the 1930s, it was already being extracted and purified from a woman's urine and sold commercially as a hormone replacement therapy. In 1931, scientists first extracted 'androsterone', the chemical precursor of testosterone, which itself was identified, synthesized, and utilized by the second half of the 1930s. Experimentation on the functionality of the sex hormones was also well under way. Apart from their use in fertility medicine, the sex hormones were known to influence and improve general health and well-being. Montalenti welcomed future research on their 'rejuvenating' and anti-aging properties for both men and women, but condemned the work of Russian and German scientists along these lines, because they involved experiments to transplant the testicles of monkeys to man. Of great potential benefit to humanity, he stated, would be advances in 'selective fecundation'; pre-implantation selection for sex and disease would free human beings from so many illnesses and do away with the need for sterilization, which could never be justified or condoned on any grounds, either moral or scientific. ${ }^{109}$ Montalenti's world of biogenetics was far removed from that of his forebear, Mantegazza, the pioneer of IVF; but it was already moving implacably in the direction of those that followed, such as Antinori, who would push the frontiers of reproductive medicine and technology still further, into the realms of pre-implantation diagnosis (PGD), genetic screening for disease, and human cloning.

\section{Conclusion}

The period of disruptive change from the 1890 s to the 1920 s which gave rise to 'the modern' spawned eugenics and fascism as forms of confrontation and

109) Montalenti. Problemi della riproduzione, $162 \mathrm{ff}, 307-8$, 316; Montalenti was still writing and thinking about biological race right up to the 1980s. The Department of Genetics, at the University of Rome, houses his personal papers: Carte Montalenti, b. 45, f. 3 'Razza e razzismo', contains material on Darwinism and racism. 
encounters with modernity. With regard to sex and reproduction, fascism was not a kind of 'reactionary anti-modernism' so much as a modernist attempt to appropriate, commandeer, and re-configure the private realm and the human economy. 'Traditional' sex and gender roles were not simply to be restored; rather, they were to be re-made according to the dictates of modern science and the modern state, both ruled by an all-commanding fascism and its all-embracing racio-socio-biological political programme. Eugenics and fascism were more than just a species of discourse, a category of language, or a type of consciousness about modernity, however. In the case of Italy, eugenics was a key component and organizing principle of the new type of state planning and regulation which fascism envisaged and effected as part of its biopolitical vision of a New Italy, New Age, and New Imperium. Science was an important tool by which fascism attempted to shape and make modernity in its own image. Under fascism, 'the modern' was a demonstrable fact, not just a discursive reality. The scientific knowledge and approach which fascism used to build its own racial utopia affected not just 'the social' and society, but also 'the biological' and bodies too.

The advancement of repro-genetics under fascism, which was evidenced in sciences as diverse as zoology and biotypology, demonstrates that Italian fascism's race/population/welfare/family/and health policies were the instruments of a scientific and scientistic modernity. Already in interwar Italy, no clear-cut distinction between eugenics and genetics could meaningfully be made. As practiced in the laboratory and the clinic, both were based on the desire to apply biology socially by means of an ambitious and comprehensive programme of socio-biological engineering which was devised by biomedicine and directed by the state. Eugenics and genetics were seen by those working within these fields, and by those in government who supported them, as allied and joint 'sciences of life' devoted to the same high purpose of the betterment of the Italian race and humanity as a whole through the fascist government's vast enterprise of what one supporter called 'social biology' ('biologia sociale'). ${ }^{110}$ Until he was forced to flee Italy for Brazil in 1938, because of the laws against the Jews, Carlo Foà (1880-1971), the distinguished biologist, physiologist, doctor, geneticist and endocrinologist, wrote, at Mussolini's invitation, a regular column for Gerarchia, the official organ documenting the march of the 'fascist revolution', entitled 'Cronache scientifiche' ('Scientific chronicles'). Enjoying a huge mass readership, his features praised fascism for being a 'unique force' in the world and charted the progress of its ambitious programme of what he, and many of his contemporaries themselves called

110) A. Niceforo. 'Scienza della vita e metodo statistico: profilo di una statistica biologica.' Difesa Sociale, 12 (1933) 6, 287-303. 
'biological politics' ('politica biologica'). Fascism had far-reaching plans for the Italian race which were to be commended because they were pro-life and proconceptive. And in his lectures in medicine at the University of Milan, Foà emphasized that eugenics and fascism shared the same vision and mission about improving the quality and quantity of the race. Every action of the regime emanated from this single intention, which constituted the defining purpose of fascism in Italy. ${ }^{111}$

Referring to what has come to be called 'biopolitics', a term now laden with Foucaultian baggage that scholars either love or hate, those writing in the $1930 \mathrm{~s}$ recognized that a conception of biological race occupied the common ground between eugenics and fascism. Both shared, moreover, a form of biological determinism predicated on the belief that the best way to safeguard the hereditary patrimony of the Italian race was by means of fertility increase. Well before the formal commencement of the 'Fecund Decade' in 1928, Mussolini's pronouncements on the birthrate underscored resoundingly the biological dictates and racist conceptualizations of the Italian variety of generic fascism. To the assembled people of Reggio Emilia, for example, Mussolini declared his support of a population policy based upon eugenic principles in 1926. He emphasized the procreative, regenerative, and generative impulses that inspired fascism. 'We need to create ourselves; we of this epoch and this generation, because it is up to us, I tell you, to make the face of this country unrecognizable in the next ten years'. He spoke of the desire to create a New Italian 'according to our own imagination and likeness'. In conversation with Emil Ludwig in 1932, furthermore, he spoke at length about his conviction that the fascist enterprise of re-making Italians had to begin at the core somatic and cellular level of human biology. He expressed his firm belief that the demographic campaign in existence since 1925 would in a short space of time engineer changes and improvements not just in the character and behaviour of people, but also, more fundamentally and more beneficially for the race in the long term, in the biological and bodily make-up of individuals. ${ }^{112}$ For Mussolini himself, the demographic campaign and the ideas and initiatives behind it were the prerequisite and foundation for all fascism's endeavours, in economics, foreign policy, and the domestic sphere. As it was understood by contemporaries, fascist 'biological politics' and the 'racism' upon which this was premised were manifest on a daily basis in the concrete actions of government.

111) C. Foà. 'Gli studi di genetica ed il problema demografico.' Gerarchia, 1929; 'Aspetti biologicistatistici del problema demografico.' Gerarchia, 1931; L. Lojacano, ed. Popolazione e fascismo. Roma: L'Economia Italiana, 1933, 183.

112) M. S. Quine. Italy's Social Revolution. 129-34; A. Gillette. Racial Theories in Fascist Italy. 41-2: C. Ibsen. Dictating Demography: The Problem of Population in Fascist Italy. New York and Melbourne: Cambridge University Press, 1996, 65-68. 
The entire political programme of fascism in power was reducible to a 'defense of the race'.

Race, reproduction, and biology were central to Italian fascism in ways that are not yet fully explored or understood by scholars. In the realm of ideas, they resided at the very core and comprised the essence of so-called fascist 'palingenesis.'113 And, more empirically, they constituted the driving force behind the realities and praxis of fascism in power. Far beyond the rhetorical, the pursuit of hyperfecundity, manifested in the new repro-medicine, had the power to affect and transform people's lives and bodies. The Italian fascist dictatorship did not subject science and medicine to 'totalitarian' control in an unreciprocal and unilateral way. Rather, it harnessed and utilized pre-existing traditions of pronatalist nationalism and racism within eugenics and the larger culture. A mutually beneficial relationship arose in which the state directed and rewarded those medico-scientific agendas that supported its own political aims and eugenic science and medicine influenced directly the content of government policy and played a part in the re-structuring of Italian society, institutions, the state and culture that took place under fascism. This is especially so in the 1930s, which witnessed the ascendancy of biotypology, genetics, and biomedicine. Italian eugenics was a heterogeneous movement with evolving ideas and shifting foci. The more numbers-based approach of Gini gave way after the Rome conference, which represented the apogee of Gini's power and influence, to the more bodies-based perspective of Pende on the problem of how best to increase population. The range of social interventions which already comprised Mussolini's war against race suicide was increasingly accompanied by a host of biological interventions designed to combat racial sterility at the psycho-somatic level. The effectiveness of the many health and welfare reforms introduced after 1925 was to be enhanced by the promotion of new forms of repro-medicine designed to increase fertility.

Within eugenic studies, the Italian national case study provides an interesting example. Not only can we see here eugenics actually in action, in government initiatives, which is seldom in evidence, but also we have a novel and somewhat anomalous road towards racial 'utopia' followed. This was, unusually, a 'state eugenics', which was thoroughly institutionalized by fascism. Historians have tended, moreover, to categorize eugenics as being either 'positive' or 'negative' in nature. However, Italian eugenics charted a path that represented a perceived 'safe', 'Third Way' option between hereditarianism and environmentalism. This distinctly Italian eugenics bridged the apparent divide between 'nature' and 'nurture' and 'quality' and 'quantity'. The forces that

113) R. Griffin. The Nature of Fascism. London: Pinter, 1993. 
shaped this trajectory were eugenics' own pre-existing, pre-war pronatalist nationalism and racism, its re-foundation as eu-genetics, its embrace of biology, biotypology, and orthogenesis, as well as the directive influence of a very determined fascist dictatorship. Through these, Italian eugenics as a whole found a means to reject birth control, contraception, sterilization and other forms of antinatalism, including marriage bans, without sacrificing the aspiration of biological improvements to the race which comprised the Galtonian 'first principle' of the science. At no point in its history from 1913 to the time of its gradual dissolution after 1949 did Italian eugenics collectively endorse any negative measure at any society meeting or congress. To attain population increase through a multi-pronged pronatalism in all policy spheres and, simultaneously, improve human biology and eradicate disease through preventative medicine, operating broadly at many levels of clinical and social practice, was a very attractive proposition for eugenicists and fascists alike.

Eugenics 'Italian-style' had some distinctive features, not the least of which was the conceptualization and construction of the Italian 'hyperfecund' New Man and New Woman as a select and superior race of human being. Italian eugenics associated reproductive fitness with physical robustness and correlated these with a whole host of positive and desirable racial attributes. It re-fashioned traditional notions of 'femininity' and 'masculinity' along lines dictated by the new biopolitics and its search for technocratic and 'totalitarian' rationality and perfection in the production of healthy and fertile individual and social bodies. Human fertility and reproduction became the epistemic objects of scientific research, medical practice, and political action in fascist Italy. For Italian eugenics and fascism, the 'hyperfecundity' of the Italians, perceived and constructed as a psycho-somatic trait and as the basis for racial supremacist arguments, had the same ontological significance as purity of race did for German eugenics and fascism. Fascism took credit for having turned the flabby, effeminate, feminist and unfertile Italians of the liberal, democratic past into hard men/real men and soft women/maternal women of the fascist present. The highly sexualized, normative idealizations of the 'average' or 'normal' Italian male and female as super-fit and super-fecund appealed to the priapic male fantasies and misogynistic perceptions at the base of fascism.

On one level, eugenics is reducible to an understanding of which human attributes were the most highly esteemed in any given place or time. The set of social and biological qualities that Italian eugenicists believed was worthy of propagation is a good point of contrast with eugenic movements elsewhere and reveals significant differences in national approaches. English eugenicists engaged in an eternal search for the 'man of genius' who had many intellectual virtues, but few animal or procreative or physical attributes. In stark contrast 
to Italian ideas about racial degeneration and superiority, a Puritanism and prudishness ran through much of American thinking along these lines. In the United States, adolescent males in the grip of strong hormonal urges and the so-called sexual perversion of masturbation (along with 'bastard-bearing', welfare-dependent, single mothers) were seen as being capable of bringing down WASP civilization single-handedly. An anti-sexuality accompanied forms of antinatalism in America and elsewhere. A highly charged homoeroticism fuelled a strain of German fascism; and homosexuality was known to be rife within the SS. ${ }^{114}$ But the masculine and feminine ideal-types of Aryan extolled endlessly in Nazism's propaganda were largely de-sexualized repositories of ascetic values. In Italy, however, the connections between sex and eugenics and fascism were of an entirely different nature. Fear of race 'pollution' through interbreeding with blacks in Italian East Africa, for example, was predicated on the belief that it would deplete the sex vigour and reproductive fitness of the white master race of colonizers and civilizers. Italian eugenics and fascism promoted a biological nationalism predicated upon a conviction that raw and rampant sexuality of a heterosexual variety was the source of racial superiority. The hedonistic and eroticized body, social, and racial ideals that went into the vision of Hyperfecund Man and Woman as the apex of human evolution, beauty, and achievement contrasted sharply with the rejection of sex and sexuality, emphasis upon self-restraint and sexual repression, the pursuit of mental and physical health by the control of 'base' animal instinct and the cultures of ascetism operating in Germany, as well as Northern Europe and North America. ${ }^{115}$ With regard to the problem of 'generic' fascism, these differences played out in the utterly different cults of the leader operative in Fascist Italy and Nazi Germany. Whilst the Duce was presented as the embodiment of the eugeni-fascist ideal of a super-fit, super-virile superman, the Fuhrer was represented as a god-like supreme being devoid of the sexual or bodily impulses of mere mortals.

The creation of biologically re-engineered highly fertile and fit superhuman beings, made to its own specifications, was the ultimate fascist ambition. Far beyond the realm of rhetoric, Italian fascism promoted the advancement of scientific research into fertility and the medical treatment of infertility. Though it did so to further the aims of its biopolitical programme, the dictatorship, nonetheless, aspired to make readily available on a voluntary basis (though

114) K. Theweleit. Male Bodies: Psychoanalysing the White Terror. Cambridge: Polity Press, 1989, 335; G. J. Giles. 'The Denial of Homosexuality: Same-Sex Incidents in Himmler's SS and Police.' Journal of the History of Sexuality, 11 (2002) 1-2 (Special Issue: Sexuality and German Fascism), 256-290.

115) E. Peeters, L. Van Molle, and K. Wils. 'Introduction: A Historical Exploration.' In Beyond Pleasure: Cultures of Modern Asceticism. Eds. E. Peeters, L. Van Molle and K. Wils. New York, Oxford: Berghahn, 2011, 1-18, 12. 
only to married, heterosexual couples) fertility treatments which, if successful, had the far-reaching potential to enhance immeasurably the quality of life of people struggling with infertility. This reality suggests a far more complex and complicated history of fascist natalism than has been explored in much of the literature, which has focused on the negative, coercive, and conservative character of the regime's imposition of models of 'compulsory' motherhood and fatherhood, as well as the methods employed by people to avoid pregnancy. The dictatorship did instruct Italians to breed prolifically. In so doing, however, it did more than just draw upon the values of 'traditional' Catholic Italy. In its scientific form, fascist natalism could be supremely anti-Catholic; and it could be too a liberating and progressive force, at least with regard to the treatments being developed under state sponsorship to help infertile couples and to combat genetic disease. Fascism advanced bio-genetic science and repro-medicine in the restrictive milieu of an overwhelmingly Catholic society in which the church still claimed absolute primacy and control over all matters relating to sex, reproduction, and the family. By fostering the development of pioneering techniques to combat racial 'sterility', it consciously extended the boundaries of knowledge about reproduction and promoted the cause of scientific modernity. As current battles between church, state, and society over the confines of reproductive technologies now amply demonstrate, moreover, the fascist regime charted new territory boldly in its encouragement of scientific advances in assisted conception. For the race, though not for the individual, fascist biopolitics extended the reproductive 'rights' of the infertile, though in an undemocratic context. Mussolini's dictatorship also championed a form of reproductive, social, and sexual radicalism, secularism, and progressivism whose legacy and implications still reverberate loudly today. 